\title{
An integrative look at SARS-CoV-2 (Review)
}

\author{
MIGUEL A. ORTEGA ${ }^{1-3^{*}}$, OSCAR FRAILE-MARTÍNEZ ${ }^{1 *}$, CIELO GARCÍA-MONTERO $^{1}$, \\ SANDRA GARCÍA-GALLEGO ${ }^{2,4}$, LARA SÁNCHEZ-TRUJILLO ${ }^{1,3}$, DIEGO TORRES-CARRANZA ${ }^{5}$, \\ MIGUEL ÁNGEL ÁLVAREZ-MON ${ }^{1,2,6}$, LEONEL PEKAREK ${ }^{1}$, NATALIO GARCÍA-HONDUVILLA ${ }^{1,2}$, \\ JULIA BUJAN $^{1,2}$, MELCHOR ÁLVAREZ-MON ${ }^{1,2,7^{*}}$, ÁNGEL ASÚNSOLO ${ }^{2,8,9^{*}}$ and BASILIO DE LA TORRE Á,10* $^{2,8,10}$
}

${ }^{1}$ Department of Medicine and Medical Specialties, Faculty of Medicine and Health Sciences, University of Alcalá, Alcalá de Henares, 28801 Madrid; ${ }^{2}$ Ramón y Cajal Health Research Institute (IRYCIS), 28034 Madrid;

${ }^{3}$ Tumor Registry, Pathological Anatomy Service, Prince of Asturias University Hospital, Alcalá de Henares, 28801 Madrid;

${ }^{4}$ Department of Organic and Inorganic Chemistry, 'Andrés M. del Río' Institute of Chemistry (IQAR),

University of Alcalá, CIBER-BBN, 28805 Madrid; ${ }^{5}$ First of May Health Centre, Health Area I, Rivas Vaciamadrid,

28521 Madrid; ${ }^{6}$ Department of Psychiatry and Medical Psychology, Infanta Leonor University Hospital,

28031 Madrid; ${ }^{7}$ Internal Medicine Service, Prince of Asturias University Hospital, CIBEREHD, Alcalá de Henares,

28805 Madrid; ${ }^{8}$ Preventive Medicine and Public Health Area, Department of Surgery, Medical and Social Sciences,

Faculty of Medicine and Health Sciences, University of Alcalá, Alcalá de Henares, 28801 Madrid, Spain;

${ }^{9}$ Department of Epidemiology and Biostatistics, Graduate School of Public Health and Health Policy,

New York University, New York, NY 10027, USA; ${ }^{10}$ Traumatology Service,

Ramón y Cajal University Hospital, 28034 Madrid, Spain

Received September 3, 2020; Accepted December 4, 2020

DOI: $10.3892 /$ ijmm.2020.4828

\begin{abstract}
SARS-CoV-2 is a newly discovered member of the betacoronaviruses and the etiological agent of the disease COVID-19. SARS-CoV-2 is responsible for the worldwide pandemic which has been taking place in 2020, and is causing a markedly higher number of infections and deaths compared to previous coronaviruses, such as SARS-CoV or MERS-CoV. Based on updated scientific literature, the present review compiles the most relevant knowledge of SARS-CoV-2, COVID-19 and the clinical and typical responses that patients have exhibited against this virus, discussing current and future therapies, and proposing strategies with which to combat the disease and prevent a further global threat. The aggressiveness of SARS-CoV-2 arises from its capacity to infect, and spread easily and rapidly through its tight interaction with the human angiotensin-converting enzyme 2 (ACE-2) receptor. While
\end{abstract}

Correspondence to: Professor Ángel Asúnsolo, Preventive Medicine and Public Health Area, Department of Surgery, Medical and Social Sciences, Faculty of Medicine and Health Sciences, University of Alcalá, Campus Universitario-C/19, Av. de Madrid, Km 33,600, Alcalá de Henares, 28801 Madrid, Spain

E-mail: angel.asunsolo@uah.es

*Contributed equally

Kew words: SARS-CoV-2, COVID-19, immune response, targeted drug delivery, prevention and clinical management not all patients respond in a similar manner and may even be asymptomatic, a wide range of manifestations associated with COVID-19 have been described, particularly in vulnerable population groups, such as the elderly or individuals with other underlying conditions. The proper function of the immune system plays a key role in an individual's favorable response to SARS-CoV-2 infection. A hyperactivated response, on the contrary, could account for the more severe cases of COVID-19, and this may finally lead to respiratory insufficiency and other complications, such as thrombotic or thromboembolic events. The development of novel therapies and vaccines designed to control and regulate a proper immune system response will be key to clinical management, prevention measures and effective population screening to attenuate the transmission of this novel RNA virus.

\section{Contents}

1. Introduction

2. Molecular features of SARS-CoV-2 infection

3. Epidemiology and economic burden of COVID-19:

Examples of Italy and Spain

4. Diagnostic and preventive methods

5. Immune system and SARS-CoV-2

6. Endothelial cell involvement and effects of SARS-CoV-2

7. Systemic manifestations of SARS-CoV-2

8. Therapies in use and under development

9. Nanotechnology-based strategies for the treatment, prevention and diagnosis of COVID-19

10. Proposals for control 


\section{Introduction}

Severe acute respiratory syndrome coronavirus 2 , or SARS-CoV-2, is the name of the virus responsible for the pandemic disease Coronavirus Disease 2019 (COVID-19) discovered in Wuhan (China) in December, 2019, from where it spread to the whole province of Hubei and and subsequently worldwide $(1,2)$. The Coronaviridae family of the order Nidovirales is divided into 2 subfamilies Orthocoronavirinae and Torovirinae. The family Orthocoronavirinae has 4 described genera: Alphacoronavirus, betacoronavirus, gammacoronavirus and deltacoronavirus (3). In total, 7 species are known to infect humans, four of which $(\mathrm{HCoV} 229 \mathrm{E}, \mathrm{HCoV}$ NL63, HCoV HKU1 and HCoV OC43) have been linked to mild cold-like symptoms in immunocompetent individuals, while two of them, SARS-CoV originating in China and Middle East respiratory syndrome coronavirus (MERS-CoV) in the Middle East, were responsible for a large number of deaths due to severe respiratory infections in 2003 and 2012, respectively $(4,5)$. SARS-CoV-2, similar to SARS-CoV and MERS-CoV, belongs to the genus betacoronavirus, whose species cause zoonotic infections that may affect humans (6). Nevertheless, it is SARS-CoV that shares most characteristics with SARS-CoV-2, having approximately $80 \%$ homology with its genome (7).

Bats seem to be a natural reservoir for coronavirus. However, the mechanisms whereby these viruses can affect other species, including human beings, are not yet well understood (8). Some scientists have suggested that, as has occurred with SARS-CoV and MERS-CoV, there is an intermediate as yet unidentified host that acts as the real reservoir for SARS-CoV2. Identifying this host is essential to prevent the transmission of this virus. Thus far, the pangolin was considered to be the most likely candidate, although other animals such as minks, snakes or even some turtle species have not been ruled out (9-11). However, despite its origin as a zoonotic disease, the most frequent mechanism through which SARS-CoV-2 causes infection is via human-to-human transmission. The main route of this spread is through droplets containing viral particles produced when a person sneezes or coughs. These droplets are able to settle on mucous membranes in the mouth, nose and eyes of individuals in close proximity, or the virus is acquired through contact with contaminated objects (fomites) or surfaces (12). Other proposed routes are the fecal-oral route (13) or even vertical transmission (14).

The incubation period for the virus has been estimated to be approximately 5-7 days, although in certain cases it can be as long as 14 days. The reproduction rate of SARS-CoV-2 (reflecting its contagiousness) is approximately 2.2-2.6, and its average serial interval (time elapsed between when symptoms appear in a transmitting person until they appear in an infected individual) is 7.5 days (15-17). Viral load is another important factor for the transmission of this virus. It is known that the greater viral load is found in the upper respiratory tract until 3 days after symptoms begin. However, transmission has been also described in some individuals at 1-3 days prior to the onset of symptoms, indicating the viral load may be sufficient for its transmission even before symptoms arise (18). Furthermore, it is also considered that asymptomatic individuals can also transmit this virus to other individuals (19). These data need to be kept in mind to prevent the spread of SARS-CoV-2.

\section{Molecular features of SARS-CoV-2 infection}

Coronaviruses are large $(80-220 \mathrm{~nm})$, enveloped, positive-sense single-stranded RNA (+ssRNA) viruses. Their genome is the largest of all RNA viruses and can be up to $33.5 \mathrm{~kb}$. SARS-CoV-2 is a Baltimore group IV virus, meaning its genome is a +ssRNA whose mRNA is identical to the viral genome (20). The term coronavirus refers to the crown shape that its proteins make up when observed by electron microscopy (21). Structurally, coronaviruses are composed of nucleoproteins that envelope the +ssRNA, forming a nucleocapsid. This nucleocapsid is bounded by a lipid envelope with 2 or 3 structural proteins anchored to the membrane. A major characteristic of betacoronaviruses is that they usually have haemagglutinin-esterases (22). The genome of coronaviruses is a highly conserved structure characterized by the presence of a replicase gene preceding structural and accessory genes. This last group of genes will express non-structural proteins by ribosomal frameshifting (23), while 4 structural proteins are encoded by coronaviruses: E, N, M and S protein. The sequence of the genome is: 5'-replicase- S-E-M-N-3' (22). Of note, Phan (24) reported the presence of a wide range of mutations and deletions in coding and non-coding regions in 86 genomes of SARS-CoV-2, confirming its mutagenic capacity and the rapid evolution of this coronavirus.

$S$ protein, or spike surface protein, plays a prominent role in the entry of SARS-CoV-2 in the host cell by interacting via the viral receptor binding domain (RBD) with the human angiotensin converting enzyme 2 (ACE-2) receptor. The structure of this domain is strongly conserved and exhibits a high degree of similarity with that of SARS-CoV. Nonetheless, some differences have been described at the C-terminal residue conferring SARS-CoV-2 a greater affinity for ACE-2 (25). Importantly, this homology means that some therapies targeting the spike protein used against SARS-CoV may also prevent the entry of SARS-CoV-2 into the cell (26). Recently, neuropilin-1 (NRP-1), a protein strongly expressed in the olfactory tract, has been identified as a novel molecular target of SARS-CoV-2 entry $(27,28)$. Walls et al (29) demonstrated that $\mathrm{S}$ glycoprotein has a furin cleavage site between subunits S1 and S2, which is important in the processing of the protein. Similarly, these authors also described multiple conformations of S protein through cryo-electron microscopy, highlighting the importance of structural studies for the development of future vaccines and specific inhibitors.

Once inside the cell, the virus replicates its genome starting with the replicase gene. Coronaviruses contains 2 or 3 proteases, which will model the initial polyprotein forming this transcript. Non-structural proteins then bind to form a replicase-transcriptase complex, promoting RNA replication and transcription. During this process, genomic and subgenomic RNA are produced serving as templates for structural and accessory genes (18).

Coronaviruses are distinguished through their strong recombination capacity favoring the appearance of novel coronaviruses with unpredictable consequences for humans (30). This ability is due to the non-structural protein, nsp12, also known as RNA-dependent RNA polymerase (RdRp) and has been proposed as a promising target for COVID-19 therapy (31). 
Finally, novel molecular targets are emerging as therapies for SARS-CoV-2 infection. Examples are Mpro protease, a key enzyme for coronavirus replication and transcription (32), or $\mathrm{M}$ protein, which plays a main role in coronavirus morphology and assembly (33) through its interaction with other components, such as $\mathrm{E}$ and $\mathrm{N}$ protein. $\mathrm{M}$ and $\mathrm{E}$ protein are responsible for formation of the lipid envelope and $\mathrm{N}$ protein is needed for nucleocapsid stabilization, giving rise to $\mathrm{N}$ protein-RNA and an inner core of virions, thus concluding this process $(34,35)$.

As has been reported, when infecting a cell, SARS-CoV-2 gains entry by attaching to the host ACE-2 receptor. ACE-2 expression is widely distributed in different human tissues, although not all cells that express this enzyme are susceptible or may be involved in the pathogenesis of COVID-19. There are other factors, such as host age, sex, ethnicity, or the presence of comorbidities that may modulate ACE-2 expression and its role in COVID-19 (36). Pulmonary epithelial cells, particularly alveolar epithelial cells or type 2 pneumocytes, exhibit a high ACE-2 expression and are considered to act as a reservoir for viral replication and invasion (37). Type 2 pneumocytes constitute $60 \%$ of alveolar epithelial cells. These pneumocytes are essential for surfactant synthesis and secretion, xenobiotic metabolism, and water flow on the lung surface and alveolar epithelial regeneration following lung damage (38).

Thus, damage to these type 2 pneumocytes can lead to irreversible lung damage. Moreover, some histological features related to SARS-CoV-2 have been found in common with SARS-CoV, such as diffuse bilateral alveolar damage, the formation of hyaline membranes and pulmonary edema in response to pneumocyte type 1 damage (39). This means that SARS-CoV-2 may infect any alveolar epithelial cell. Apart from ACE-2, transmembrane protease serine 2 (TMPRSS2) seems equally important for the entry of SARS-CoV-2 into the cell. The virus enters the cytosol via the proteolytic cleavage of viral spike surface protein through human proteases, such as cathepsin or TMPRRS2 followed by viral particle-to-membrane fusion (18). Notably, the expression of both human receptors, ACE-2 and TMPRSS2, has been detected in bronchial transitory secretory cells, and a higher activity of RHO GTPase has been found to promote susceptibility to COVID infection (40). In an ex vivo model of pulmonary SARS-CoV-2 infection, the quantity of viral antigen $(\mathrm{N})$ is markedly higher than in SARS-CoV models, producing up to 3.2-fold more viral particles, thus explaining its greater infectivity (41).

The emergence and rapid spread of SARS-CoV-2 has led to devastating consequences on global health and the economy. Its clinical features indicate that it is able to evade human immune surveillance much more effectively than SARS-CoV. Its high infectivity, mutagenic capacity and ability to evade the immune system are contributing to its worldwide spread. Understanding the molecular mechanisms responsible for these characteristics of the virus are key to gaining control of the virus through novel treatments, vaccines, diagnostic and screening techniques and preventive measures. Only through a coordinated multidisciplinary approach on the part of researchers, healthcare and non-healthcare professionals will we be able to curb the spread of SARS-CoV-2 $(42,43)$. The present review article summarizes the relevant data on the epidemiology and social and clinical management of COVID-19, and discusses the more notable discoveries of basic and translational research proposing measures to effectively combat this global concern.

\section{Epidemiology and economic burden of COVID-19: Examples of Italy and Spain}

While SARS-CoV was responsible for approximately 8,000 infections and 800 deaths, MERS-CoV affected fewer individuals and was restricted to Saudi Arabia and a small area of South Korea (44). To date (November 17, 2020), by contrast, SARS-CoV-2 has infected 54,771,888 individuals and has been responsible for a staggering 1,324,249 deaths (45). According to these latest figures, the mortality ratio is $2.46 \%$, much lower than the $9.5 \%$ reported for SARS-CoV, or the $30 \%$ attributed to MERS-CoV (46). Nevertheless, this percentage notably varies, depending on the country or the moment; presently, this ratio has been estimated at $15.23 \%$ in several countries, such as France and at $<\%$ in Israel or Russia (47). In addition, it is proving difficult to accurately identify individuals affected by SARS-CoV-2 and hence, its real associated mortality. For instance, individuals with no access to diagnostic tests or with false negative test results are not taken into consideration, as are asymptomatic individuals or those not seen at a healthcare center. Furthermore, variations in the criteria selected to report probable and confirmed deaths due to COVID-19 may notably complicate estimates (48). The vast majority of affected individuals fall within the age group of 30-79 years, and in these individuals, COVID-19 usually presents with mild symptoms or as non-severe pneumonia (49). By contrast, elderly individuals or individuals with a chronic disease or cardiopulmonary insufficiency, often require monitoring primarily 1-2 weeks following the onset of symptoms (50). In children, SARS-CoV-2 infection is less usual, and symptoms are less severe. This may be due to lower exposure to sources of contagion or maybe they become infected in a manner similar to adults; however, cases are more often subclinical due to biological differences in the functioning of their immune system. Despite all these factors, children do not seem to be an important reservoir of SARS-CoV-2 $(51,52)$. Other observations indicate that males are more severely affected than females. The different explanations put forward for this have been, for instance, a greater exposure of males to certain work environment or social factors, such as smoking, the better efficacy of the innate immune response in females or even biological differences in ACE-2 activity (53). Moreover, pregnant women with COVID-19 seem to exhibit the same clinical manifestations as adults, although SARS-CoV-2 infection may increase the risk of complications during pregnancy or labor $(54,55)$.

According to the latest data from the World Health Organization (WHO), $>43 \%$ of all cases of COVID-19 have occurred in the USA $(22,438,205$ cases) followed by Europe (14,487,598 cases) and South-East Asia (9,908,674 cases) (45). In Europe, Italy and Spain were the most affected countries during the first wave along with France, where the first case of COVID-19 was reported in individuals arriving from China in mid-January, 2020 (56). Initially, Italy, and particularly, its northern region, was the hardest-hit country in Europe, and rapidly became the second country with the majority of cases 
and deaths associated with COVID-19 worldwide. Containment measures began on March 9-11, and March 21st was the day with the highest number of infections recorded in Italy $(57,58)$. According to the Italian Ministry of Health, the average age of COVID-19 patients was 62 years, while 81 year-old-patients exhibited the highest mortality rate, those with 3 or more comorbidities being particularly susceptible (59). Spain went into full lockdown on March 14th, 13 days after the start of the exponential rise in infections (60). Patients 50 to 59 years of age were the most commonly affected and the disease was described as potentially lethal in individuals $\geq 80$ years of age (61). In Italy, lockdown was continued until May 3rd, and measures to curb local or regional outbreaks were introduced, such as social distancing (maintaining a $1.5 \mathrm{~m}$ safety distance), the use of masks, avoiding crowds and limiting the number of persons in social events (62). These measures were also implemented in Spain, where lockdown easing was conducted in 4 stages (0 to 3 ) until reaching a state of 'new normality' (63). According to the last data collected by the WHO from January-February to November, 2020, Italy had 1,178,529 confirmed cases and suffered 45,229 deaths; however, of note, from May to October of this year, the number of new infections and mortality have plateaued (64). During the same time period, Spain has similarly registered 40,769 deaths and a total of 1,458,591 cases although many of these cases have arisen in the last 3 months (65). Italy and Spain are examples among several other countries of a lack of effective measures taken, identifying a need to redirect measures for better management of the situation. Apart from causing human suffering, this pandemic has also affected the economy of each country. According to the International Monetary Fund (IMF), a 12.8\% reduction in the GDP growth rate is predicted for Spain and Italy $(66,67)$. To minimize economic impacts on businesses, the Spanish government has pledged a 200 billion Euros rescue package whereas the package proposed for Italy is 25 billion Euros (68). The economic burden of COVID-19 is a serious concern worldwide and a concerted approach is required to mitigate its impact on all sectors. In the face of such turmoil, the hopes of country leaders, researchers and healthcare systems are turning to the introduction of an effective vaccine against SARS-CoV-2.

\section{Diagnostic and preventive methods}

A diagnosis of SARS-CoV-2 can be made according to its clinical manifestations, such as fever (88.7\%), unproductive cough $(67.7 \%)$, dyspnea (45.6\%), fatigue (29.4\%) and other less frequent symptoms, such as myalgia, sore throat, productive cough, headache, diarrhea, sickness and/or vomiting and dizziness, in that order (69). Even so, as described below, there is also another set of clinical manifestations that may be associated with COVID-19; however, the presence of these symptoms may not be sufficient to make an accurate differential diagnosis; thus, it is necessary to be able to rely on efficient molecular tests. There are 2 most commonly used molecular tests to diagnose the virus: Cell cultures and PCR. In the case of SARS-CoV-2, the performance of cell cultures has exhibited a very low efficiency due to a delay of at least 3 days to detect the presence of this virus (70). Thus, RT-qPCR is the most feasible molecular test owing to the early characterization of the viral genome. The first RT-qPCR protocol was published on January 23rd, and targeted the genes RdRp, E and N, whose relevance will be detailed below (71). Since then, multiple kits have been developed, allowing for a more rapid and more sensitive detection of COVID-19. An example is a slight modification of the initial protocol proposed by Chan et al (72) that targets RdRp/helicase (hel), $\mathrm{S}$ and $\mathrm{N}$ genes to avoid cross-reactivity with other coronaviruses. Its efficacy, however, varies according to the laboratory conducting the test. These techniques pursue a high sensitivity and quick diagnosis (73). They have effectively exhibited a high efficiency to detect viral particles in different clinical samples like bronchoalveolar lavage, sputum, saliva, throat and nasopharyngeal samples (25). Other diagnostic methods may be especially useful, as is the case of imaging techniques used to examine lung structure, e.g., computed tomography, which can be faster, more sensitive and hence more reliable, particularly for individuals with fever as a clear symptom (74). Imaging tests are less useful, however, for population screening as they require visits to a hospital.

Measures implemented to prevent and stop the spread of SARS-CoV-2 have focused on avoiding infected individuals spreading the virus and also preventing non-affected individuals to come into contact with the virus (75). One of the measures that is having more impact is as simple as hand washing; $15 \mathrm{sec}$ can be sufficient to kill up to $90 \%$ of pathogens on a hand, and $30 \mathrm{sec}$ to eliminate $99.9 \%$. The conclusion is that appropriate hand hygiene can prevent 16 to $21 \%$ of respiratory viral infections in the general population (76). However, this precaution may not be sufficient to protect healthcare personnel from SARS-CoV-2, as this virus seem, similar to other coronaviruses, exhibits a high resistance on a wide variety of surfaces such as metal, glass or plastic. The accurate inhibition and elimination of the virus is necessary, as it has been shown that contact with contaminated surfaces can lead to the inadvertent self-inoculation of mucous membranes in the nose, eyes or mouth $(77,78)$. A review article written by Kampf et al (79) examines the most appropriate measures for the correct decontamination of fomites. One example is the use of ethanol $62-71 \%$, hydrogen peroxide $0.5 \%$ and sodium hypochlorite $0.1 \%$ over a $1-\min$ time period. The efficiency of this method was described as greater than the use of benzalkonium chloride $0.05-0.2 \%$, chlorhexidine digluconate $0.02 \%$. Other preventive measures recommended by the WHO for the general population consist of avoiding transmission to other individuals by restraining drops from sneezing or coughing using masks, apart from maintaining a safety distance of $3 \mathrm{~m}$ (80). The protective equipment recommended include masks, particularly surgical masks or N95 respirators that prevent contact with contaminated droplets from the mouth and nose, which supposedly are the 2 main entry routes of SARS-CoV-2 (75).

At the community level, other types of measures have been implemented, as is the case of quarantine, one of the most effective measures used to contain the spread of various infectious diseases throughout history, with the objective of attenuating the contagion curve. In infected individuals, quarantine should be at least 2 weeks to prevent infection spreading to other individuals (81). In healthy individuals, different countries have imposed different lengths of quarantine based on factors, such 
as population screening. Models, such as that of South Korea have been particularly successful. One of its secrets has been the rapid development of massive diagnosis centers, where in merely $10 \mathrm{~min}$, a person can be tested. This screening is organized as a registration center and a brief questionnaire, whereby individuals are referred to a test center for sample collection and are provided with instructions and detailed information (82). Measures such as this serve to control not only the infected population, but also the healthy one, facilitating counts and avoiding dissemination. Notwithstanding, this strategy and epidemiological surveillance has met with some difficulties. For example, patients who have had the disease will continue to return a positive RT-PCR test, which is not the case with other infectious diseases (83). Consequently, continuous communication and coordination between all countries is warranted, apart from governments, institutions and professionals from different fields, to establish accurate measures and reliable information for the population, also highlighting a sense of social responsibility.

\section{Immune system and SARS-CoV-2}

The connection between SARS-CoV-2 and the immune system is one of the main points of study to fully understand the pathogenesis and impact that COVID-19 may have on patients, as well as to develop novel effective therapies. When SARS-CoV-2 binds to a cell through the host receptors ACE-2 and TMPRSS2, it replicates inside the cell and following the release of virus particles, the virus promotes host cell entry into pyroptosis. Infected cells signal various pattern recognition receptors (PRRs), such as Toll-like receptor 7 (TLR-7), retinoic acid-inducible gene I (RIG-1), melanoma differentiation-associated protein 5 (MDA5) and the cyclic GMP-AMP synthase (cGAS)/stimulator of interferon genes (STING) pathway, thus recognizing viral components such as RNA or even cytosolic DNA of the affected cell, promoting the production of type I interferon (IFN-I) and other inflammatory cytokines (84). Simultaneously, damage-associated molecular patterns (DAMPs) are also produced, such as adenosine triphosphate (ATP) or genetic content. The presence of DAMPs in the tissue will activate the innate immune response in the lungs, mainly mediated by granulocytes, antigen presenting cells (APCs) and pro-inflammatory macrophages $(85,86)$. In a proper immune response, this system is coordinated and supported by an adaptive immune response, represented by $\mathrm{CD}^{+} \mathrm{T}$ cells, $\mathrm{CD}^{+} \mathrm{T}$ cells, Tregs and $\mathrm{B}$ cells. The activation and proliferation of $\mathrm{CD}^{+} \mathrm{T}$ cells fosters $\mathrm{CD} 8^{+} \mathrm{T}$ cells, crucial for antiviral responses through the induction of cell death. Likewise, B cells secrete antibodies to neutralize the virus or induce the lysis of infected cells by complement activation or antibody-dependent cellular cytotoxicity (mediated by natural killer (NK) cells) (85). The effectiveness and coordination of this response will finally determine the recovery of the patient. Notwithstanding, severe cases of COVID-19 exhibit a low efficacy of the immune response, causing cell and tissue damage with systemic implications characteristic of this disease when compared to other respiratory infections, such as severe lymphopenia and eosinopenia, pneumonia with lung damage, acute respiratory distress syndrome (ARDS), along with other systemic alterations $(87,88)$.
The course of COVID-19 presents in 3 main stages: Stage I, characterized by primary production of $\operatorname{IgM}$ antibodies, and stage II characterized by exacerbated lung inflammation accompanied by cytokine storm (89). Stage I with mild manifestations is the incubation time and the time of preparation for the adaptive immune response to try to eliminate the virus. This response is mobilized if the virus outpaces the innate immune response in situations of a poor health state or if there are other comorbidities or in the elderly. Firstly, the innate immune response begins with the activation of TLRs 3,7 and 8 signaling transduction and boosted IFN production. The humoral, or adaptive, response commences with the production of antibodies against viral $\mathrm{N}$ and $\mathrm{S}$ proteins, $\mathrm{IgG}$ and IgM, which may appear 4-8 days later. However, if this initial protective phase fails, the virus disseminates causing multiorgan involvement through the ACE-2 receptor. In stage II, or the so-called macrophage activation syndrome, an intense inflammatory response is established featuring the overexpression of cytokines and chemokines $(87,90)$. Eventually, a third stage may be distinguished if therapy is ineffective against stage II, including multiorgan failure and hyperinflammation with typically more severe symptoms. At this point, anti-viral treatment will not be effective unless combined with anti-inflammatory and anti-rheumatic drugs (91). These are the 3 stages of COVID-19 proposed by Siddiqi and Mehra (92) as summarized in Fig. 1. An awareness of these events is crucial to design strategies for the prevention of severe disease, the better management of patients (89) and to ensure the safety of physicians (90). With the purpose of containing the virus and preventing the disease progressing to a severe physiopathology, the most appropriate time for the administration of each drug is under debate, as it discussed below.

The main event responsible for an aberrant response is the phenomenon known as the cytokine storm. Beta coronaviruses are capable of interacting with the immune system via the membrane and non-structural proteins forming the virion, hence disrupting IFN-I signaling (93). This failure is a trigger for the massive uncontrolled secretion of cytokines, which will cause the cytokine storm. In addition, it is known that the higher the viral load, the more likely this defective response, which is equally related to severity (94). Epithelial respiratory cells, dendritic cells and macrophages produce and secrete greater levels of cytokines, among which the following have been highlighted: Interleukin (IL)-1 $\beta$, IL-1RA, IL-2, IL-6, IL-7, IL-10, IFN- $\gamma$ (type II) tumor necrosis factor- $\alpha$ (TNF- $\alpha$ ), IL-8, monocyte chemoattractant peptide (MCP)-1, macrophage inflammatory protein (MIP)-1A, MIP-1B and granulocyte-colony stimulating factor (G-CSF) (95).

The effect of cytokines in COVID-19 will depend on the stage of the disease in which they are produced as well as host features. For instance, it is known that IL-6 is one of the most important molecules in the immune system for combatting SARS-CoV-2, although the role of this cytokine in COVID-19 has not yet been completely elucidated. Firstly, IL-6 seems to promote a proper adaptive immunity response by boosting Tregs, $\mathrm{CD}^{+} \mathrm{T}$ cells and $\mathrm{B}$ lymphocytes, amongst other effects. By contrast, IL-6 can promote the polarization of Th lymphocytes to Th2 or Th17 at the expense of Th1 lymphocytes, which may have aberrant effects on tissue integrity, extracellular matrix (ECM) 


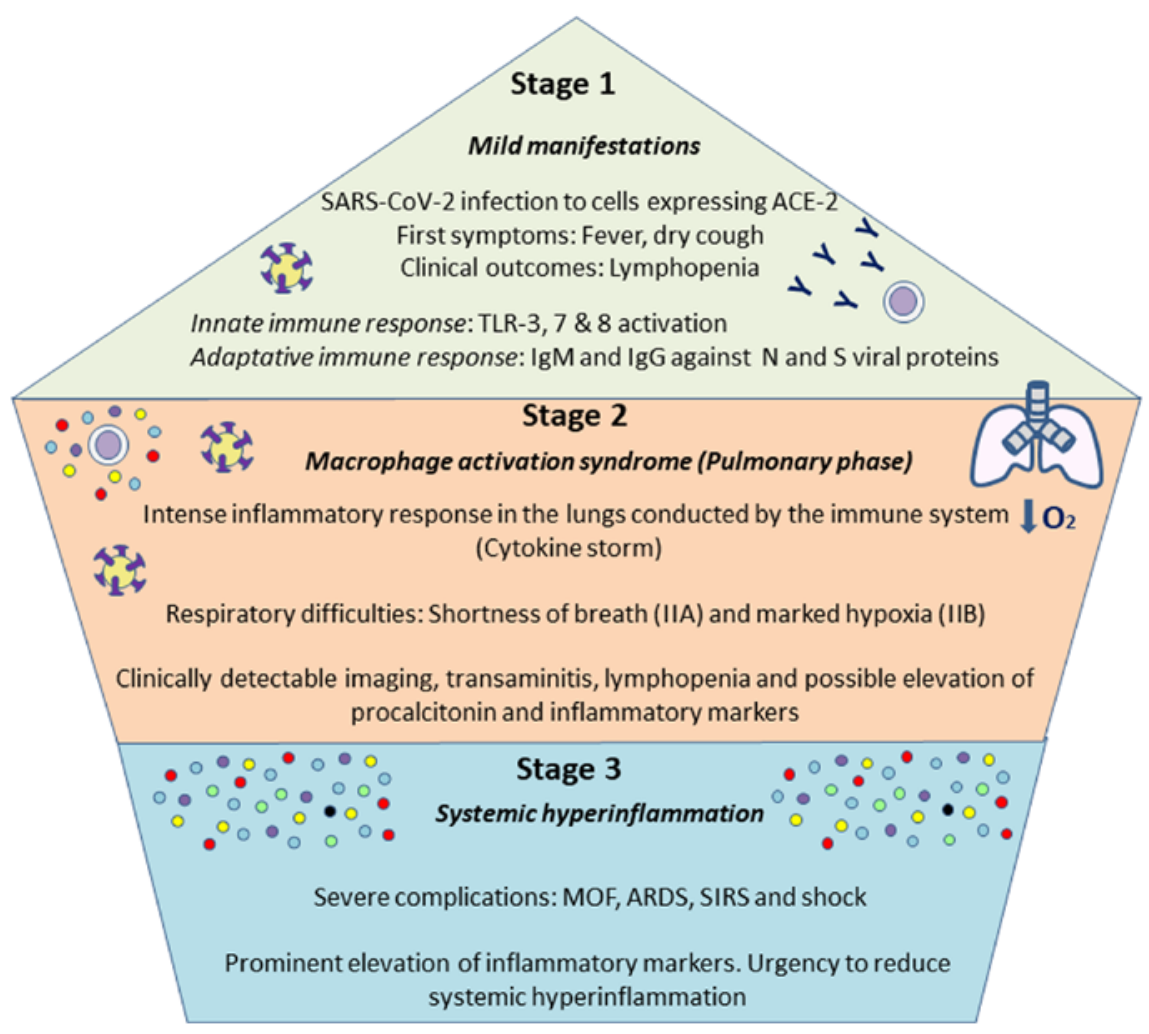

Figure 1. Stages of SARS-CoV-2 course. As proposed by Siddiqi and Mehra (92), 3 main phases can be distinguished in COVID-19. The first one is associated with mild symptoms, and individuals infected will develop and innate and adaptatively responses, being able to eliminate the virus. If not, a more severe pulmonary stage will take place, causing a pneumonia without (IIA) or with hypoxia (IIB), with an aberrant release of cytokines. The third stage is an hyperinflammation status, defined by a cytokine storm and possibly leading to the most severe symptoms, including ARDS, SIRS or MOF. Addressing the different complications during the various phases will be vital for a proper management of the disease. ARDS, acute respiratory distress syndrome; SIRS, systemic inflammatory response syndrome; MOF, multi-organ failure.

structure and the maintenance of pro-inflammatory neutrophils and macrophages (96). Consequently, in patients with severe ARDS, the overactivation of T cells seems to occur, with a considerable increase in Th17 and $\mathrm{CD}^{+} \mathrm{T}$ cell cytotoxicity (97). This effect may be associated with IL-6 hypersecretion. Consistent with previous research, Zhang et al (98) reported an IL- 6 concentration $>10 \mathrm{pg} / \mathrm{ml}$ in all samples collected from 82 patients that succumbed to COVID-19, thus linking higher levels of this cytokine with its detrimental effects during the cytokine storm. Notably, these authors also reported findings, such as a neutrophil/lymphocyte ratio $>5$ or elevated levels of inflammatory markers, such as $\mathrm{C}$ reactive protein (CRP). Similarly, a decrease in $\mathrm{CD}^{+} \mathrm{T}$ cells and $\mathrm{CD}^{+}$lymphocytes has been described in severe cases of COVID-19 (99).

This cytokine storm, along with disrupted IFN-I signaling, will further induce the apoptosis of lung epithelial and endothelial cells, thus leading to ARDS and multi-organ failure (MOF) $(100,101)$. ARDS leads to major respiratory damage, and is responsible for up to $70 \%$ of the total demise produced by COVID-19 (98). During ARDS, epithelial-endothelial barrier integrity is disrupted, promoting the entry of macrophages, and aggravating lung damage which in turn will facilitate virus dissemination (102). ARDS caused by COVID-19 has some peculiarities compared to other infections, including greater damage to epithelial than endothelial alveolar cells and clinical manifestations such as a lower exudation or a delayed onset of the symptoms from 8 to 12 days (103).
The susceptibility of the main risk groups to severe COVID-19 may also have its origin in the immune system response. Non-communicable diseases (NCDs) such as obesity, type 2 diabetes mellitus, renal insufficiency, liver disease, etc. are importantly related to low-grade chronic inflammation, characterized by immune system malfunction with systemic implications (104). This state favors the exacerbation of the immune response, the knowledge of which may be essential for proper clinical management of these patients $(105,106)$. Excessive adipose tissue, typical of NCDs, is considered to act as a reservoir for SARS-CoV-2, and this may have a synergic effect with chronic inflammation (107). Elderly individuals present further significant alterations in their immune function. Aging causes immunosenescence and disruptions in innate and adaptive immune responses involving Th involution, which reduces efficiency to recognize antigens and coordinate defense mechanisms, such as the defective production of antibodies, thus providing a reason for the vulnerability of these patients to SARS-CoV-2 infection $(84,108)$.

On the contrary, the immune system may be reinforced and prepared to minimize its negative effect against SARS-CoV-2. Immunity is the result of complex interactions of genetic and acquired factors, such as hormone, metabolic, psychological and lifestyle factors or an individual's microbiota. Diet has been identified as a relevant factor, in that the western pattern of consuming 'fast food' and limited vegetable consumption promotes the activation of the innate immune response and simultaneously impairs the performance of the 
adaptive system (109). A healthy dietary pattern, such as the Mediterranean diet which is abundant in plant-based foods and healthy fats could contribute to an appropriate immune response, due to the intake of components, such as omega-3 fatty acids. Omega-3 has been attributed a role in immune system resolution during sepsis (110). Immune resolution is one of the most intriguing mechanisms proposed to slow down the cytokine storm responsible for COVID-19 progression (111). Thereby, a healthy diet may play a key role in the prevention of SARS-CoV-2 infection or reduce its severity (109). Likewise, adherence to physical activity recommendations and a positive psychology are equally critical for maintaining a healthy immune system (112).

On the whole, the immune system response in patients with COVID-19 remains an essential topic of study. The overactivation of the immune system produces the cytokine storm, which is one of the most important alterations in severe cases of COVID-19 (Fig. 2). An early diagnosis, pharmacotherapy and a healthy lifestyle can reverse or control this aberrant response, thus supporting the clinical management of SARS-CoV-2 infection.

\section{Endothelial cell involvement and effects of SARS-CoV-2}

The endothelium is one of the most affected structures associated with COVID-19, having important consequences when there is an underlying disease, such as thrombosis, renal disease or cardiovascular compromise, among others $(113,114)$. The vascular endothelium is one of the organs that more significantly expresses the ACE-2 receptor (115). Consequently, the endothelium is proposed as a SARS-COV-2 target. In the study by Varga et al (116), the presence of viral particles was detected in endothelial cells, along with an accumulation of inflammatory cells.

Both the inflammatory response and the infection can activate the endothelium, leading finally to its dysfunction associated with greater platelet and leucocyte activation, along with altered anticoagulant and fibrinolytic mechanisms detected through some serum markers such as increased levels of D-dimer, C-reactive protein or TNF- $\alpha$ (117). In fact, elevated serum levels of some of these compounds have been linked to a poorer prognosis and a greater severity commencing early on (118). Accordingly, therapy against endothelial damage and its complications is an interesting target for severe cases of COVID-19 (119).

Neutrophils can be recruited by activated endothelial cells and they can also activate the coagulation cascade through the production of neutrophil extracellular traps (NETs) in a coordinated manner with monocytes and platelets (120). These NETs are comprised of a DNA blend with different toxic compounds present in the cytosolic granules of these neutrophils that are released in an explosive way in a process known as NETosis (121).

Investigators are beginning to propose that fibrin formation occurs in the bosom of NETS after coagulation begins in its intrinsic and extrinsic pathways (122). The activation of endothelial cells renders them and monocytes, with their microvesicles, to express the tissue factor and activate the extrinsic pathway of coagulation that leads to fibrin deposition and clotting (123). NETs are regulated by their associated proteins, such as NE, cathepsin G and tissue factor pathway inhibitor (TFPI), the negative regulator per excellence of the extrinsic pathway (124). In the case of the intrinsic pathway, the histones present in NETs interact with platelets, both with phospholipids and TLRs $(125,126)$. According to research, vascular occlusions are caused by the inability of the organism to eliminate these NETS, particularly during sepsis (127). In fact, using different techniques these NETs have been used as reliable measures of sepsis and thrombosis (128). Likewise, NETs are also involved in the cytokine storm, contributing to the secretion of IL1 $\beta$, which in turn increases NETs and the production of other important cytokines like IL-6 (129). Thus, NETs are yet other interesting target for managing the complications of COVID-19.

NETs are not the only mechanisms that promote these alterations. Zhang et al (130) reported that increased serum levels of antiphospholipid antibodies may be involved in thrombus formation. In parallel, Escher et al (131) described increased levels and activity of the von Willebrand factor (VWF), arising from activation and damage to the endothelium promoting its release from Weibel-Palade bodies. The levels of coagulation factor VIII are also increased in these patients. Furthermore, fibrin deposits have been found in pulmonary parenchyma due to the expression of tissue factor in this tissue with a decrease in plasminogen activator inhibitor 1 (PAI-1) creating a hypo-fibrinolytic status (132).

Therefore, on the whole, endothelial dysfunction and its impacts give rise to some of the major complications of COVID-19 (Fig. 3). Improving knowledge of the alterations produced in the endothelium during infection and trying to control its response could benefit patients.

\section{Systemic manifestations of SARS-CoV-2}

In December, 2019, scientists began to suspect that a novel coronavirus was emerging due to a series of patients in the Chinese city of Wuhan who presented with pneumonia of unknown etiology as the main clinical manifestation, along with dyspnea, fever and cough $(133,134)$. These cases resembled the symptoms produced by SARS-CoV and MERS-CoV in previous years (135). Following the worldwide spread of the pandemic, further clinical manifestations have been added to define a complex syndrome. Several of these manifestations are related to expression of the ACE-2 receptor in the different tissues of the human body (136-139) and include a notably array of respiratory symptoms along with cardiovascular, neurological, gastrointestinal, hematological, renal and dermatological alterations (Fig. 4).

However, it should be highlighted that diagnostic tests have confirmed the existence of individuals with COVID-19 that remain asymptomatic, whose role as carriers of this infection has become a controversial issue $(140,141)$.

Respiratory manifestations. Respiratory manifestations were first used as criteria for suspected cases of infection. These manifestations are related to the presence of the ACE-2 receptor in the respiratory tract and the special tropism of the virus for this site (137). Fever and cough are the most common symptoms. Other symptoms are fatigue, anorexia, myalgia; as well as expectoration, dyspnea and chest tightness $(118,142,143)$. 


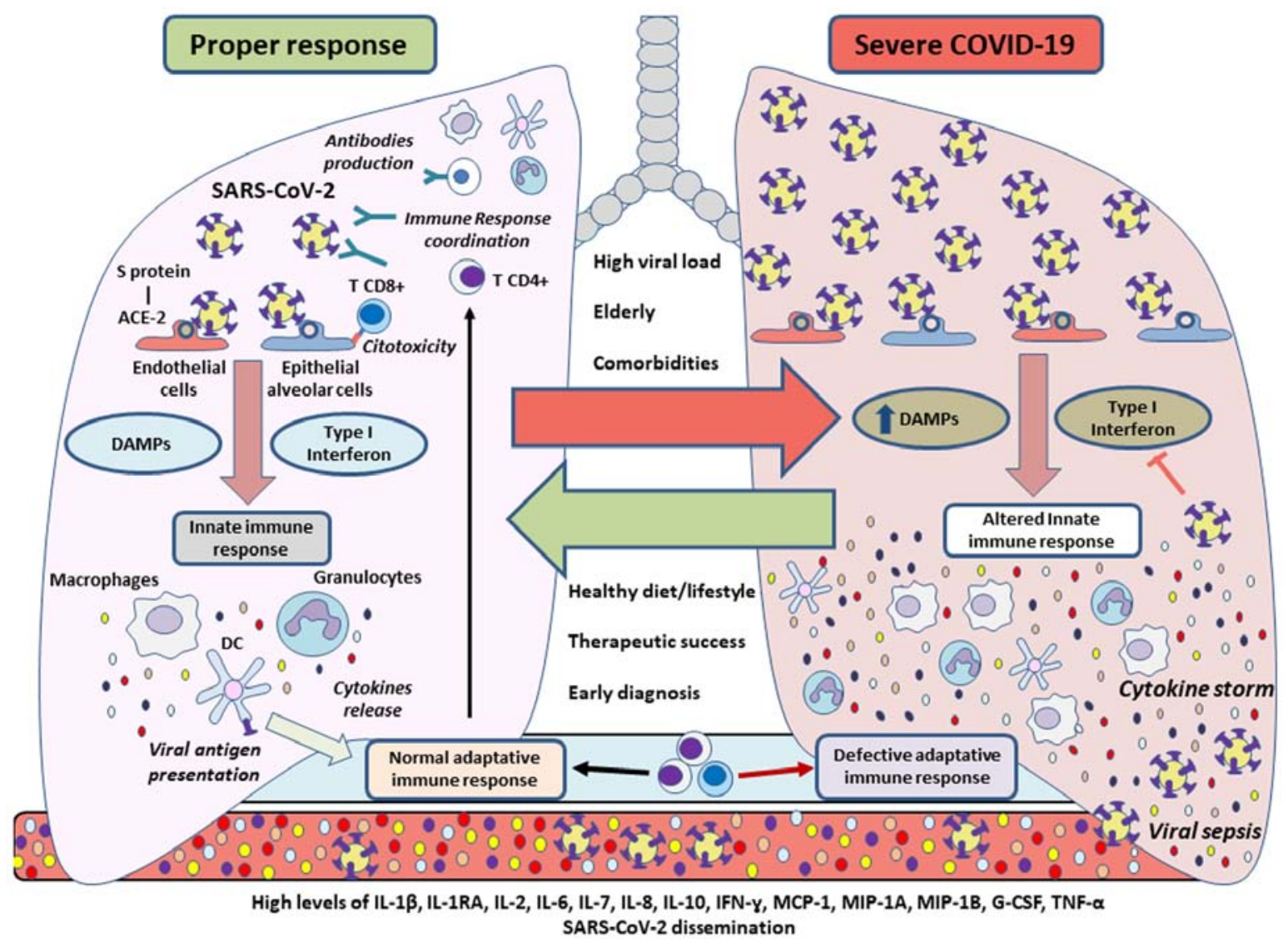

Figure 2. Immune response during SARS-CoV-2 infection. When there is a proper defense mechanism, the innate immunity of an individual will give rise to cytokines, while carrying out antigenic presentation, promoting and enhancing a coordinated adaptive immune response to combat the virus. SARS-CoV-2 could inhibit type I interferon-mediated signaling, affecting the innate immune system by additionally acquiring more DAMPs, thus leading to a cytokine storm. This aberrant response could promote tissue damage as well as viral sepsis, which may be detected in blood tests. A high viral load, advanced age or underlying disease are usually associated with severe cases of COVID-19, whereas a healthy lifestyle or diet, successful pharmacotherapy and an early diagnosis could prevent the complications of COVID-19 promoting a rapid recovery by controlling the immune response. DAMPs, damage-associated molecular patterns; IL, interleukin; IFN- $\gamma$, interferon $\gamma$; MCP-1, monocyte chemoattractant protein-1; MIP, macrophage inflammatory protein; G-CSF, granulocyte colony-stimulating factor; TNF- $\alpha$, tumor necrosis factor $\alpha$.

The majority of patients develop symptoms of pneumonia, characterized by being uni- or bilateral (more frequently), typically peripheral, with ground glass opacities and $>3$ lobules affected. In severe cases, the infection can lead to ARDS associated with severe hypoxemia and respiratory failure that requires mechanical ventilation (142). Two different clinical phenotypes have been described: Type 'L' ('low elastance') and type 'H' ('high elastance'). Phenotype 'L', apart from a low elastance (i.e., high compliance) is characterized by a low ventilation-to-perfusion ratio, and low lung recruitability; thus, perfusion is the main factor limiting pulmonary function. Phenotype ' $\mathrm{H}$ ' is characterized by a high elastance, a high right-to-left shunt and high lung recruitability. In this phenotype, ventilation is the main limiting factor of pulmonary function (144).

Cardiovascular manifestations. During the course of infection, biomarkers, such as troponin, BNP and NT-proBNP may rise. However, there are no associated electrocardiographic changes or symptoms (145). Moreover, the increase produced in these biomarkers is related to clinical severity (146). The presence of cardiovascular risk factors, such as hypertension, diabetes or obesity has been linked to a poor outcome $(139,147)$. Some authors claim that obesity is an essential prognostic factor, as obese patients exhibit higher mortality rates and greater intubation and oxygen requirements (148). Endothelial cells also feature the ACE-2 receptor. The virus has been held responsible for endothelial dysfunction and endotheliitis, leading to a variety of symptoms according to effects on the different organs and systems of the human body (116), as described below. A higher prevalence of distal vein thrombosis has been described in patients with COVID-19 (149), and this has also been associated with higher levels of D-dimer (150).

Gastrointestinal manifestations. Since the beginning of the pandemic, gastrointestinal manifestations, such as nausea, vomiting, abdominal pain and diarrhea have been associated with COVID-19 (151) due to viral tropism and the presence of the ACE-2 receptor in the gastrointestinal tract $(138,139)$. These symptoms may be attributed to gastritis and enteritis caused by virus infection. In the majority of patients with gastrointestinal manifestations, diarrhea seems to be the most common and is usually limited to a median duration of 4 days. All these manifestations are usually associated with other typically described symptoms, such as fever or cough $(133,143,151)$. Gastrointestinal symptoms have been associated with a fever up to $38.5^{\circ} \mathrm{C}$ and family clustering (151). A higher ratio of chronic liver disease has also been described, 


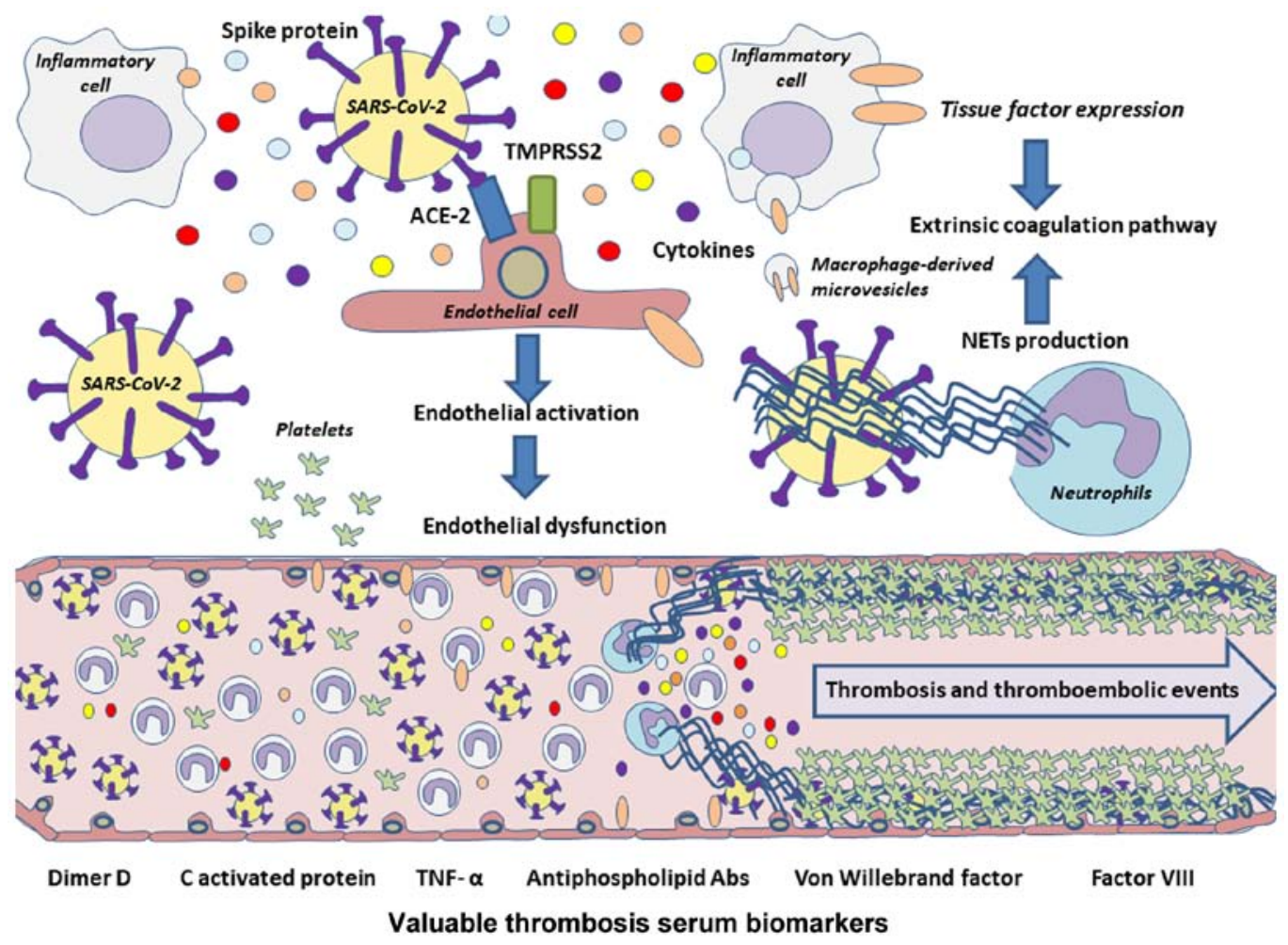

Figure 3. Pathophysiology of thrombotic and thromboembolic events associated with COVID-19. Owing to the high expression of the ACE-2 receptor by endothelial cells, they could be a potential targets of SARS-CoV-2, which may lead to endothelial cell activation and finally to endothelial dysfunction. Cytokines released during a cytokine storm also promote endothelial damage, and along with inflammatory cells and their microvesicles, the extrinsic coagulation pathway may be activated through further tissue factor expression. In addition, NETs could lead to activation of coagulation pathways, acting as inhibitors of the negative extrinsic pathway regulator TFPI, besides boosting the production of proinflammatory cytokines, such as IL-6 or IL-1 $\beta$, both leading to platelet coagulation and therefore to thrombosis or thromboembolisms in these patients. NETs, neutrophil extracellular traps; IL, interleukin; TFPI, tissue factor pathway inhibitor; TNF- $\alpha$, tumor necrosis factor $\alpha$.

as well as increased bilirubin, ALT and aspartate aminotransferase (AST) levels $(133,152,153)$. Through PCR, the presence of the virus has been detected in saliva (154) and feces (155), indicating the important effects SARS-CoV-2 may have on the gastrointestinal tract.

Hematological manifestations. During the course of infection, normal leucocyte counts are present in $60 \%$ of patients, and a number of patients exhbit lymphopenia (47\%) and high PCR levels $(65.9 \%)(133,156)$. Patients also feature elevated levels of transaminases (AST, ALT and lactate dehydrogenase $(\mathrm{LDH}))$ and cardiac enzymes, D-dimer, VSG and procalcitonin. Leukocytosis and increased levels of procalcitonin indicate the viral origin of the infection, as is already known. Increases in these parameters can also be related to disease severity (145). Low platelet counts have been described in patients with severe COVID-19 and this may be considered a poor prognostic factor (157).

Neurological manifestations. The presence of the ACE-2 receptor in the vascular endothelium explains the specific neurotropism of SARS-CoV-2 (158). Neurological symptoms are present in 36.4\% of patients with COVID-19 (159). Headaches are the most common symptom, while other neurological symptoms, such as dizziness, loss of consciousness, stroke and convulsions have been described. Notably, Liguori et al (159) described subjective neurological symptoms, particularly sleep disturbances in $90 \%$ of a cohort of
103 patients hospitalized due to COVID-19. Manifestations affecting the peripheral nervous system include hypogeusia, hyposmia, vision loss and neuralgia in the absence of other typical symptoms, such as fever (160). Other severe neurological manifestations have been described, such as encephalitis and meningoencephalitis (161-163). The presence of these neurological manifestations is a poor prognostic factor in patients with severe COVID-19 infection.

Renal manifestations. Kidney injury has been observed, with the elevation of serum creatinine levels in up to $10.9 \%$ of cases $(133,156)$. According to Pei et al $(164)$, patients can develop renal complications during infection, such as proteinuria, hematuria or acute renal failure. Furthermore, while almost $50 \%$ of patients recover normal renal function, mortality has been estimated to be $11.2 \%$ higher in patients with renal symptoms than without these symptoms.

Dermatological manifestations. Cutaneous manifestations of COVID-19 infection include maculopapular eruptions as the most frequent, followed by acral erythema with vesicles and pustules (resembling chilblain), urticarial lesions and vesicular eruptions (165). The more common skin manifestations seem to be exanthematous eruptions which are typically heterogeneous and show high variability on presentation (166).

Other clinical manifestations. Recent investigations have associated ocular manifestations with COVID-19 infection. In 


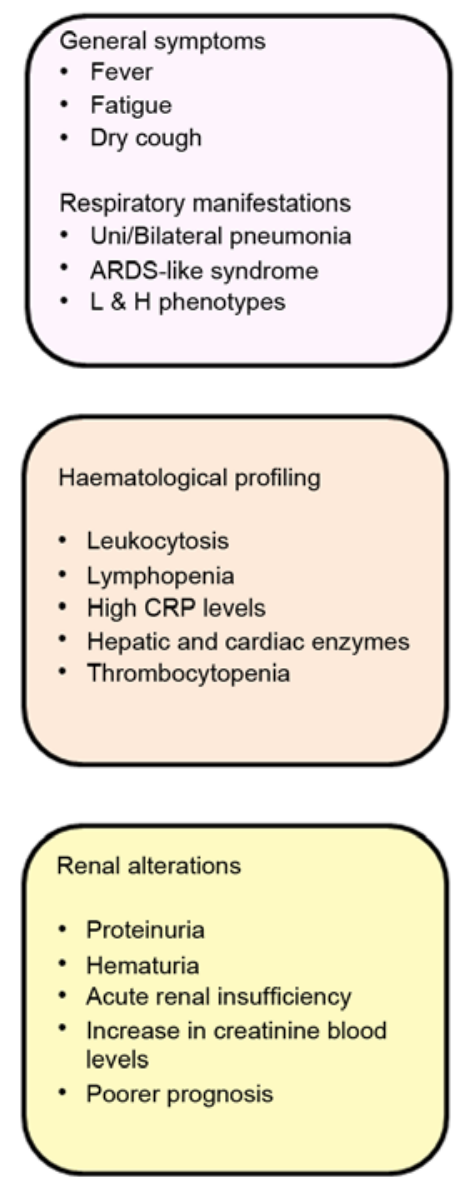

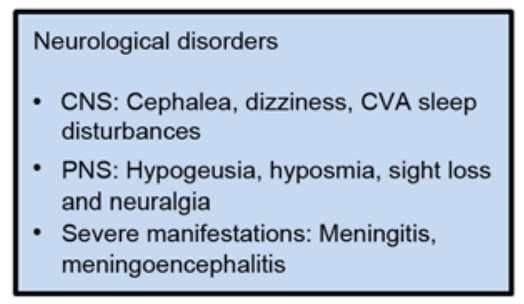

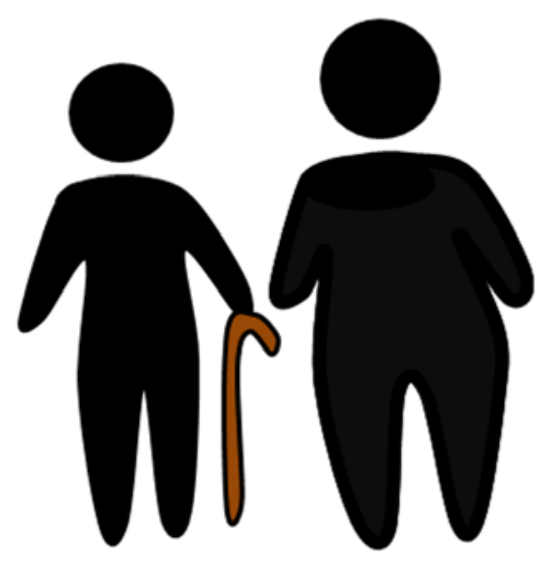

Other manifestations

- Ocular symptoms: Conjuntivitis

- Pregnant women: Adverse effects? Vertical transmission?

- Pediatric patients: Mild symptoms Cough, fever, odynophagia
Cardiometabolic implications

- Troponine, BNP, pro-BNP, dimer D increased

- Obesity, DM2, hypertension as poorer prognosis factors

- Endothelial dysfunction and endotheliitis

- Higher prevalence of distal venous thrombosis

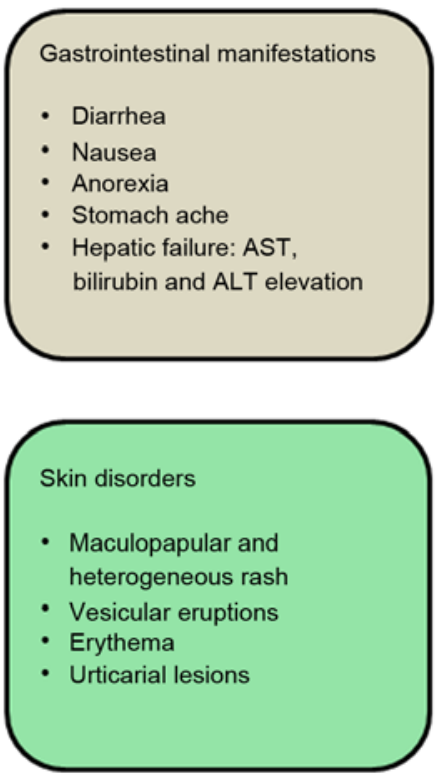

Figure 4. Clinical manifestations of COVID-19. Although general symptoms, such as fatigue, fever or dry cough and respiratory problems are typically observed, other alterations may also be found like neurological, hematological, cardiometabolic, gastrointestinal, renal or skin disorders, amongst others. Understanding these symptoms and complications could play a major role in the clinical management of COVID-19 patients, hence the importance of a multidisciplinary approach to SARS-CoV-2 infection.

a study conducted by Chen et al (167), conjunctival congestion was recorded in up to $5 \%$ of patients. Other ocular symptoms described in that study were ocular pain, photophobia, dry eye and tearing. Their multivariate regression analysis revealed an association between ocular symptoms and hand contact with ocular tissues, which is a risk factor for developing the infection. In the meta-analysis conducted by Loffredo et al (168), incidence rates differed and the incidence rate of conjunctivitis was $1.1 \%$. However, this latter study demonstrated that hospitalized patients with severe COVID-19 infection exhibited an increased incidence of conjunctivitis. Accordingly, conjunctivitis is considered a possible sign of COVID-19 infection.

Clinical manifestations in pediatric patients. In children, COVID-19 infection exhibits different typical clinical characteristics to those described in adults. This may be due to the immaturity of their tissues and immune system or to possible cross-immunity produced by the infection with other respiratory viruses (169). Its presentation in children is often asymptomatic or with milder symptoms than those in adults.

According to the meta-analysis conducted by Mustafa and Selim (170), the most common symptoms in the pediatric patients analyzed were similar to those observed in adults: Cough, fever and odynophagia; and in almost $60 \%$ of patients, the infection developed into pneumonia. The majority of patients presented with mild clinical infection and only $5 \%$ required admission to intensive care. Similar findings have been reported by Panahi et al (169) including cough, fever and other respiratory tract symptoms, as well as gastrointestinal symptoms such as abdominal pain, nausea, vomiting and diarrhea. Laboratory findings were leucopenia (19\%), lymphopenia $(21 \%)$, increased levels of C-reactive protein $(28 \%)$ and procalcitonin $(28 \%)$; and only $4 \%$ of patients presented thrombocytopenia (170). In another study by Liguoro et al (171) these findings were also reported along with increased levels of CPK and transaminases. That study, with a total sample size of 7,480 children from Italy, USA and China, also revealed that in $49.1 \%$ of pediatric patients, abnormalities were detected in a radiological examination even if they were asymptomatic. That study also estimates a mortality rate of $0.08 \%$.

In pediatric patients with severe infection, the disease duration is longer than that in adults, and they suffer septic shock and multiple organ failure as main complications (172).

Clinical manifestations during pregnancy. The most common symptoms of COVID-19 infection during pregnancy are fever, cough, dyspnea, myalgia and fatigue. The majority of patients exhibit abnormalities in radiological studies and also feature the same hematological manifestations described for non-pregnant patients (173). This latter 
study also suggested that COVID-10 does not increase the risk of adverse pregnancy outcomes. There was no evidence of vertical transmission detected as the virus was not found in amniotic fluid, cord blood, oropharyngeal samples in the newborn or breast milk.

There has been a description, however, of a neonate that tested positive for SARS-CoV-2 according to a nasopharyngeal swab. The mother had a severe case of COVID-19 infection; thus, possible vertical transmission cannot be ruled out (174). This possibility may be supported by the presence of the ACE-2 receptor in placental tissue (175).

\section{Therapies in use and under development}

Since the beginning of the pandemic, the race against time has begun in order to identify an appropriate treatment that is safe and effective against the infection caused by SARS-CoV-2. Over these months, numerous clinical trials have included a huge variety of drugs, spanning from already known antivirals used for other infections to monoclonal antibodies. According to the results obtained and the current short experience of outcomes in clinical practice, these therapeutic strategies have been adapted; however, there are currently no specific treatments available for infection with SARS-CoV-2 and a number of suggested drugs are controversial. In Spain, the majority of hospitals have internal protocols of clinical management that follow the recommendations for potential treatments of the Spanish Ministry of Health and Agencia Española de Medicamentos y Productos Sanitarios (AEMPS; Spanish Agency Of Drugs and Medical Devices) (176).

The WHO has elaborated an interim guidance for the clinical management of COVID-19. For patients with mild COVID-19, the updated guidance (177) recommends symptomatic treatment with antipyretics and adequate nutrition and rehydration. Patients with risk factors or complications should be monitored closely and should prompt urgent care. This guidance argues against antibiotic therapy or prophylaxis for patients with mild COVID-19. In addition, antibiotics should not be prescribed for patients with confirmed moderate COVID-19 unless there is bacterial infection. Supplemental oxygen therapy must be immediately administered when $\mathrm{SpO}_{2}$ $<90 \%$ or when emergency signs are present. Furthermore, fluid management must be carried out with caution, as it may worsen oxygenation.

While the clinical management of SARS-CoV-2 infection is based on general measures (close monitoring, oxygen therapy, analgesia, etc.) and support treatment in the Intensive Care Unit, numerous drugs are being investigated as possible therapeutics against this emerging disease $(178,179)$.

In stage I, intravenous immunoglobulin (IVIG) has been proposed for patients with a deficient humoral response (180) to avoid viral entry into new cells, along with chloroquine and hydroxychloroquine, two agents that reduce glycosylation of ACE-2 receptors (181). Another option is to attenuate cytokine production by disrupting the kinase signaling pathway activated following endocytosis. This treatment includes inhibitors of Janus kinase (JAK) and numb-associated kinase (NAK), such as baricitinib (182). In stage II, proposed options are anti-IL1, anti-IL-6 and anti-TNF $\alpha$ agents to reduce acute inflammation. Colchicine as an anti-IL-1 is being tested in several clinical trials (NCT04322682, NCT04527562 and NCT04360980). The WHO does not recommend corticosteroids as a prime option, although some physicians made use of these drugs when episodes of ARDS were alarming $(183,184)$.

Remdesivir has been considered a potential drug. It is a nucleotide analogue prodrug that inhibits RNA-dependent RNA polymerase, whose effects against Ebola virus were investigated by Mulangu et al (185). Its efficacy against other viruses, such as MERS has been demonstrated in vivo in rhesus macaques (186) or against Nipah virus in African green monkeys (187). Its use against SARS-CoV-2, security profile and dosing are still under investigation; however, the preliminary results in a cohort study by Grein et al in patients with severe COVID-19 indicated clinical improvement in 36 out of 53 patients $(68 \%)$ (188). In a large proportion of patients, remdesivir has been associated with adverse outcomes, such as hypotension, elevated liver enzymes, diarrhea and kidney failure, among others (189). Its use in Spain has been limited to pregnant patients and pediatric patients with severe disease (176).

Virus protease activity has been examined as a possible therapeutic target. Lopinavir and ritonavir are protease inhibitors used against HIV combined with other retroviral agents (190). Once their efficacy against SARS-Co-1 virus was established in vitro by Groneberg et al (191), these protease inhibitors were a priori used for the treatment of SARS-CoV-2 infection. The results of a clinical trial by $\mathrm{CaO}$ et al indicated no therapeutic benefits of these agents in patients with severe COVID-19 infection (192). A number of authors (193) have responded to the article in question, arguing that further information is required on its efficacy prior to abandoning its use. This controversy is being addressed in the RECOVERY clinical trial that includes 4,972 patients (1,596 treated with lopinavir/ritonavir vs. 3,376 control patients). The preliminary results again suggest no clinical benefits and advise against their widespread use (194).

Chloroquine is another drug that has been extensively used for the management of SARS-CoV-2 infection. Due to its immunomodulatory effects, this drug has been successfully used for the treatment of malaria and rheumatic diseases (195). Its action against SARS coronavirus virus was investigated in vitro in 2005 by Vincent et al (196) and it has also exhibited activity against SARS-CoV-2 and in regulating the immunological response against this virus in vitro (197). In addition, when combined with a macrolide, hydroxychloroquine has exhibited immunomodulatory synergy in in vivo and in vitro studies $(198,199)$.

However, other authors have come to different conclusions, reporting that hydroxychloroquine, associated or not with a macrolide, as a treatment for SARS-CoV-2 infection has no clinical benefits $(200,201)$. These latter results are consistent with preliminary findings of the RECOVERY clinical trial in which 1,542 patients were treated with hydroxychloroquine-macrolide versus 3,132 control patients; as no clinical benefits were observed, the widespread use of this approach is discouraged (202).

Immunotherapy involving convalescent plasma therapy, mesenchymal stem cell therapy and intravenous immunoglobulin has also been used for the treatment of or for the prevention of viral infection. Intravenous immunoglobulin (IVIG) has 
offered good outcomes in some patients with COVID-19 by improving passive immunity and the anti-inflammatory response. Mesenchymal stem cell therapy could exert an immunomodulatory effect via the secretion of anti-inflammatory factors (203).

Other agents that should be highlighted as possible candidates for COVID-19 therapy are biological drugs against IL-6, such as tocilizumab and sarilumab, or IL-1 receptor antagonists, such as anakinra $(204,205)$. Both classes of agents block the inflammatory cascade and have been successfully used in refractory rheumatoid arthritis and other autoimmune diseases $(206,207)$. Tocilizumab has exhibited potential in reducing the risk of invasive mechanical ventilation and mortality in patients with severe COVID-19 with pneumonia (208), and recent results have indicate that it may palliate symptoms rapidly (209). Anakinra has been tested in patients with ARDS, suggesting its potential use prior to stage III disease to curb the worsening of the cytokine storm; however, its benefits/drawbacks are still under discussion (210).

The association between ILs and the cytokine release syndrome in severe infection due to SARS CoV-2 has been described by McGonagle et al, setting up the theoretical framework for the potential use of this therapy (211). At the clinical level, the preliminary results of Xu et al in 20 patients with severe COVID-19 infection indicated a good response to tocilizumab in all patients in the absence of severe adverse effects (212). Furthermore, in a systematic review, Alzghari and Acuña recommend the compassionate use of anti-IL6 in patients with SARS-CoV-2 infection, as its safety and efficacy remain to be clarified (213). Likewise, numerous therapies have targeted blocking cell pathways of the inflammatory cascade, such as the JAK 1 and JAK 2 pathways (with ruxolitinib or baricitinib), and other ILs (e.g., anti-CD-23) and TNF inhibitors are still being assessed as possible therapeutic options $(214,215)$.

The systematic review of Mansourabadi et al (203) concluded that immunotherapy may be effective in improving the clinical outcomes of patients with COVID-19. The WHO guidelines recommend that these drugs should not be administered as prophylaxis outside the context of clinical trials due to their high rates of adverse effects (177).

Finally, some authors have advocated the use of certain drugs in paucisymptomatic and non-hospitalized patients. In this context, lactoferrin is one of the most promising molecules for the prevention or aid in the treatment of COVID-19. Chang et al (216) described the potential mechanisms whereby this glycoprotein may be used against SARS-CoV-2, including direct binding of lactoferrin to the virus, through binding to host cell receptors, such as heparan sulphate proteoglycans to reduce SARS-CoV-2 surfing and entry and through the inhibition of viral replication via activation of IFN- $\alpha / \beta$. Pidotimod may be equally effective for the prevention of clinical worsening by rebalancing the immune status and reducing systemic effects of disease in ambulatory adult patients without pneumonia (217). Additional strategies, such as vitamin $\mathrm{C}$ and quercetin co-administration have exhibited potent overlapping immunomodulatory and antiviral effects, and these may be useful prophylactic agents in high-risk populations or may be used as co-adjuvants with other drugs, such as remdesivir (218).

\section{Nanotechnology-based strategies for the treatment, prevention and diagnosis of COVID-19}

The advent of the electron microscopy in the late 1930s was a breakthrough in the history of virology (219). Its high resolving power enabled the detailed study of viruses and confirmed their nanometric size of between 20 and $300 \mathrm{~nm}$ in diameter (220). Antiviral therapies working at this scale, such as those provided by nanotechnology, enable efficient interaction with viral particles and thus maximize the efficacy of the therapy. The size of nanoparticles (NPs), which influences bioavailability and circulation time, and their large surface area-to-volume ratio where large drug payloads can be attached are promising properties that may overcome the challenges of traditional antiviral strategies.

Nanotechnology has long been explored for the treatment of viral infections (221). In particular, strategies targeting respiratory viruses such as influenza (H1N1) or respiratory syncytial virus (RSV) are currently in the spotlight due to similarities to SARS-CoV-2 (222). Among the multiple strategies available, three main categories of NPs are taking the lead (Fig. 5A): Polymeric NPs, inorganic NPs and peptide-based NPs (223). The battle against COVID-19 must consider 3 key principles: Early detection, monitoring and targeting (224). Relevant examples of the use of nanotechnology for the treatment, prevention and diagnosis of SARS-CoV-2 are presented herein (Fig. 5B).

Nanotechnology-based treatment. NPs play an unquestionable role as drug delivery systems (DDS) (225). By either encapsulating or binding drugs, NPs improve delivery to the desired tissue and offer controlled drug release, thus decreasing the required dose and side-effects. Typical antiviral mechanisms for NPs range from direct inactivation of the virus (e.g., graphene oxide), interference in virus attachment to the cell (e.g., silver or gold NPs, graphene oxide), blockage of viral RNA synthesis (e.g., $\mathrm{Ag}_{2} \mathrm{~S}$ nanoclusters) or oxidation of viral proteins (e.g., copper oxide NPs), among others (226).

An example of nano-sized DDS for the treatment of SARS-CoV-2 relies on chitosan-based polymeric NPs $\left(\right.$ Novochizol $\left.^{\mathrm{TM}}\right)$. These NPs strongly adhere to lung epithelial tissues, as one of the main targets of this virus. The potential to provide safe, local sustained intra-pulmonary drug release is currently being tested for the delivery of losartan aimed at reducing inflammation and viral infection. The strategy based on self-assembled peptide NPs developed by Cui et al (226) is currently being explored using a peptide that specifically and strongly binds to the spike protein of coronavirus. These NPs not only protect the peptide from degradation, but also have water-filled channels to carry antiviral drugs. COVID-19 infections frequently lead to a hyperinflammatory state characterized by a fulminant cytokine storm. To combat this situation, stable squalene-based multidrug NPs are a new approach for the targeted treatment of acute inflammation with reduced-side effects (227). Nanobodies, or single-domain antibodies, are peptide-based NPs with sizes in the range 2-4 $\mathrm{nm}$ that exhibit high stability, low immunogenicity and excellent affinity and specificity towards the epitope (228). In this context, synthetic nanobodies against the receptor-binding domain of SARS-CoV-2 spike protein are being developed as potential inhalable prophylactic formulations (229). 
A

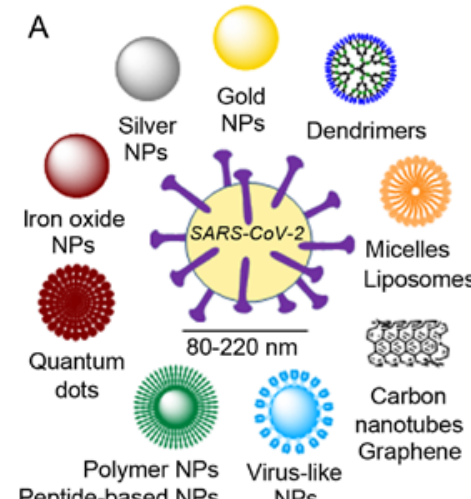

B

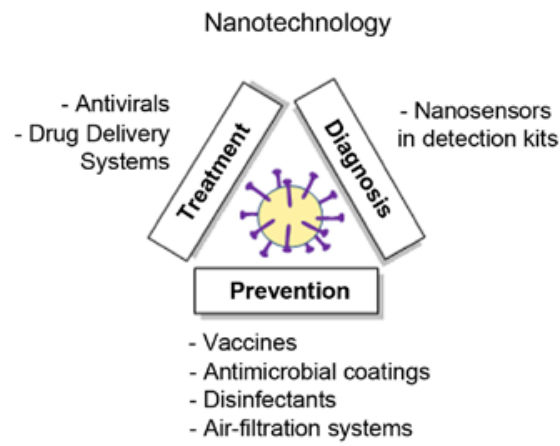

Figure 5. Examples of (A) nanoparticles and (B) nanotechnological strategies available or currently under development.

Nanotechnology-based prevention. The fierce race towards the development of an efficient vaccine for the novel coronavirus can undoubtedly benefit from the use of nanocarriers that protect their sensitive cargo, namely RNA, DNA or protein subunits. Viral vectors, a common approach in vaccine development (230), are also being explored against SARS-CoV-2 (e.g., Janssen's AdVac ${ }^{\circledR}$; TNX-1800, Tonix Pharmaceuticals; Ad5-nCoV, CanSino Biologics, currently in Phase 2; or GV-MVA-VLPTM, GeoVax). As an alternative to viral vectors, NPs have extensively been explored as gene carriers (231). In particular, different approaches are currently under pre-clinical or clinical assessment for SARS-CoV-2. In the design of RNA-based vaccines, lipid NPs are promising nanocarriers for mRNA (232), as currently explored with mRNA-1273 (Moderna Inc., Phase 1), which codes for a prefusion form of the spike protein; or with self-amplifying RNA, which is responsible for sustained protein expression inside the body and thus a vaccine response at much lower doses than traditional mRNA vaccines (233) (LUNAR ${ }^{\circledR}$, in the preclinical stage). DNA-based vaccines produce a potent immune response after the direct introduction of a plasmid encoding the desired antigens into the cells, which later will produce this antigen. For example, proteo-liposomes (Fusogenix Platform, in the preclinical stage) are being explored for the delivery of plasmids encoding multiple protein epitopes from key immunogenic SARS-CoV-2 proteins. Vaccines based on protein subunits also employ nanocarriers. NVX-CoV2373 (Novovax Inc., Phase 1/2) is a recombinant protein NP vaccine (234) able to generate antigens derived from the spike protein. Virus-like particles (VLPs) induce potent immune responses and are effective vaccines (235). The VLP strategy is used in 1c-SApNP (Ufovax $L L C$ ), comprising a one-component self-assembling protein NP with SARS-CoV-2 protein spikes protruding from the scaffold. The molecular clamp platform strategy consists of the self-assembly of a polypeptide to form an artificial enveloped virus fusion protein complex which locks the spike protein into a shape to enable the immune system to recognize it (University of Queensland). This approach has been successfully tested for viruses, such as influenza, HIV and Ebola.

While vaccines are a medium-term solution, several nanotechnology products are currently available to halt the spread of COVID-19. Nanotechnology enables or enhances the properties of different medical supplies. A broad variety of these products employ nanosilver technology, with antimicrobial, antibacterial and antiviral properties. Examples include cloths (NanoTech Micro $^{\circledR}$ ); adhesive bandages; hand sanitizers (Human Glove ${ }^{\mathrm{TM}}$ ); textiles $\left(\right.$ Xstatic $^{\circledR}$, CERTAINTYTM $^{\circledR}$ ); medical fabrics such as labcoats, curtains, bed sheets (Silver Care Plus ${ }^{\circledR}$ with X-Static ${ }^{\circledR}$ ); toilet paper and paper towels (Nanotex ${ }^{\circledR}$ ). Nanosilver-containing disinfectants are also commercialized as sanitizers, soaps and detergents. Other antimicrobial technologies include cationic nanosword coatings (NANO4-HYGIENE LIFE ${ }^{\circledR}$ ), which attract and destroy the negatively charged membranes of microorganisms; photocatalytic coatings that destroy any microbe upon activation with light, such as the mineral nanocrystals (NanoSeptic ${ }^{\circledR}$ self-cleaning surfaces) and nano-TiO $\left(\mathrm{FN}_{-N A N O}{ }^{\circledR}\right)$, used in hospitals, acute care facilities, airports, etc.; or the dual $\mathrm{TiO}_{2} /$ silver zeolite coating (Invisi Smart ${ }^{\mathrm{TM}}$ ), which has a duration of 5 years.

High-efficiency nano-based filters have been implemented in air filtration systems to prevent airborne contamination in hospitals by trapping or destroying most infectious particles (bacteria, viruses). A dense network of nanofibres is the basis behind HyperHEPA $^{\circledR}$ technology (IQAir) and nanoparticle-covered catalytic filters for photo electrochemical oxidation technology (Molekule), which destroy air pollutants through the production of free radicals upon irradiation with UV-A light. Nanofiber technology, in combination with copper dioxide NPs, is also implemented in face masks (ReSpimask $\left.{ }^{\circledR}\right)$ that trap and destroy the virus. Self-sterilizing face masks (Guardian G-Volt) are based on laser-induced graphene filters which eliminate trapped microorganisms through an electrical charge.

Nanotechnology-based diagnosis. The control of the COVID-19 pandemic requires the rapid, yet precise detection of novel coronavirus cases. Traditional detection methods that identify nucleic acids have several drawbacks including low sensitivity, lengthy protocols, a high rate of false negatives and a lack of specificity towards a particular virus. The nanometric size and multivalence of NPs can overcome these drawbacks by greatly amplifying the signal, thus decreasing the amount of samples needed and increasing the effectiveness of detection kits (236). Examples of NPs used for the diagnosis of SARS-CoV-2 include polymer-coated iron oxide NPs (237), which potently bind to the viral RNA and can be later extracted from the solution using a magnet, simplifying the purification process before RT-PCR reaction; and gold nanorods or nanoparticles (Sona Nanotech Inc. and SureScreen Diagnostics 
Ltd.) implemented in disposable quick-response lateral-flow tests, which detect COVID-19 biomarkers, IgG and IgM, within 5 to $15 \mathrm{~min}$. A different nanotechnological strategy is the use of nanopore sequencing, an electrophoresis-based tool for the sequencing of a single molecule of DNA or RNA without the need for PCR amplification. Portable DNA and RNA sequencers $\left(\mathrm{MinION}^{\circledR}\right.$ ) employ this strategy for the rapid and simultaneous detection of SARS-CoV-2 and other respiratory viruses within 6 to $10 \mathrm{~h}$ (238).

\section{Proposals for control}

SARS-CoV-2 is an emerging infectious agent that has had a marked impact on society in recent months. Although its exponential increase has diminished, the implementation of an appropriate surveillance and action strategy is required, which may aid in the control of disease outbreaks which, as had occurred with the Spanish flu, can be fatal (239). This strategy will involve a gradual return to normality while continuing to follow WHO hygiene and prevention recommendations along with individual and population screening to assess the situation at all times. Citizen awareness and appropriate coordination of governments, countries and institutions will play a key role in this ongoing process.

\section{Acknowledgements}

Not applicable.

\section{Funding}

The present review article was funded by grants from the B2017/BMD-3804 MITIC-CM (Community of Madrid, Spain) and University of Alcalá (COVID-19 UAH 2019/00003/016/001/023), co-financed by the European Development Regional Fund 'A way to achieve Europe' (ERDF).

\section{Availability of data and materials}

Not applicable.

\section{Authors' contributions}

MAO, OFM, CGM, SGG, MAAM, LST, LP, AA and BDLT were involved in the writing of the original draft and in the literature search. MAO, OFM, DTC, NGH, MAM, JB and AA were involved in the writing, reviewing and editing of the manuscript. MAM, AA and BDLT provided supervision. MAO, OFM, LP and DTC created the figures. MAM, AA and BDLT provided resources. MAO, OFM, SGG, DTC and AA were involved in the conceptualization of the study.

\section{Ethics approval and consent to participate}

Not applicable.

\section{Patient consent for publication}

Not applicable.

\section{Competing interests}

The authors declare that they have no competing interests.

\section{References}

1. Zhu N, Zhang D, Wang W, Li X, Yang B, Song J, Zhao X, Huang B, Shi W, Lu R, et al: A Novel coronavirus from patients with pneumonia in China, 2019. N Engl J Med 382: 727-733, 2020.

2. Li Q, Guan X, Wu P, Wang X, Zhou L, Tong Y, Ren R, Leung KSM, Lau EHY, Wong JY, et al: Early transmission dynamics in Wuhan, China, of novel coronavirus-infected pneumonia. N Engl J Med 382: 1199-1207, 2020.

3. Woo PC, Huang Y, Lau SK and Yuen KY: Coronavirus genomics and bioinformatics analysis. Viruses 2: 1804-1820. 2010.

4. de Wit E, van Doremalen N, Falzarano D and Munster VJ: SARS and MERS: Recent insights into emerging coronaviruses. Nat Rev Microbiol 14: 523-534, 2016.

5. Hasöksüz M, Kiliç S and Saraç F: Coronaviruses and SARS-COV-2. Turk J Med Sci 50(SI-1): 549-556, 2020.

6. Ashour HM, Elkhatib WF, Rahman MM and Elshabrawy HA: Insights into the recent 2019 novel coronavirus (SARS-CoV-2) in light of past human coronavirus outbreaks. Pathogens 9: 186, 2020.

7. Chan JF, Kok KH, Zhu Z, Chu H, To KK, Yuan S and Yuen KY: Genomic characterization of the 2019 novel human-pathogenic coronavirus isolated from a patient with atypical pneumonia after visiting Wuhan. Emerg Microbes Infect 9: 221-236, 2020.

8. Banerjee A, Kulcsar K, Misra V, Frieman M and Mossman K: Bats and coronaviruses. Viruses 11: 41, 2019.

9. Liu Z, Xiao X, Wei X, Li J, Yang J, Tan H, Zhu J, Zhang Q, Wu J and Liu L: Composition and divergence of coronavirus spike proteins and host ACE2 receptors predict potential intermediate hosts of SARS-CoV-2. J Med Virol 92: 595-601, 2020.

10. Xu J, Zhao S, Teng T, Abdalla AE, Zhu W, Xie L, Wang Y and Guo X: Systematic comparison of two animal-to-human transmitted human coronaviruses: SARS-CoV-2 and SARS-CoV. Viruses 12: 244, 2020

11. Zheng J: SARS-CoV-2: An emerging coronavirus that causes a global threat. Int J Biol Sci 16: 1678-1685, 2020.

12. Yang Y, Peng F, Wang R, Yange $M$, Guan $K$, Jiang T, Xu G, Sun J and Chang C: The deadly coronaviruses: The 2003 SARS pandemic and the 2020 novel coronavirus epidemic in China. J Autoimmun 109: 102434, 2020.

13. Yuen KS, Ye ZW, Fung SY, Chan CP and Jin DY: SARS-CoV-2 and COVID-19: The most important research questions. Cell Biosci 10: 40, 2020.

14. Peyronnet V, Sibiude J, Deruelle P, Huissoud C, Lescure X, Lucet JC, Mandelbrot L, Nisand I, Vayssière C, Yazpandanah $\mathrm{Y}$, et al: SARS-CoV-2 infection during pregnancy. Information and proposal of management care. CNGOF. Gynecol Obstet Fertil Senol 48: 436-443, 2020 (In French).

15. Jiang X, Rayner S and Luo MH: Does SARS-CoV-2 has a longer incubation period than SARS and MERS? J Med Virol 92: 476-478, 2020.

16. Lai A, Bergna A, Acciarri C, Galli M and Zehender G: Early phylogenetic estimate of the effective reproduction number of SARS-CoV-2. J Med Virol 92: 675-679, 2020.

17. Lai CC, Shih TP, Ko WC, Tang HJ and Hsueh PR: Severe acute respiratory syndrome coronavirus 2 (SARS-CoV-2) and coronavirus disease-2019 (COVID-19): The epidemic and the challenges. Int J Antimicrob Agents 55: 105924, 2020.

18. Malik YA: Properties of coronavirus and SARS-CoV-2. Malays J Pathol 42: 3-11, 2020.

19. Yu X and Yang R: COVID-19 transmission through asymptomatic carriers is a challenge to containment. Influenza Other Respir Viruses 14: 474-475, 2020.

20. Baltimore D: Expression of animal virus genomes. Bacteriol Rev 35: 235-241, 1971.

21. Englund JA, Kim YJ and McIntosh K: Human coronaviruses, including Middle East respiratory syndrome coronavirus. In: Feigin and Cherry's textbook of pediatric infectious disease. Cherry J, Demmler Harrison GJ, Kaplan SL, Steinbach WJ and Hotez PJ (eds). 8th edition. Elsevier Inc., Philadelphia, PA, pp1846-1854, 2019.

22. Park SE: Epidemiology, virology, and clinical features of severe acute respiratory syndrome-coronavirus-2 (SARS-CoV-2; Coronavirus Disease-19). Clin Exp Pediatr 63: 119-124, 2020. 
23. Fehr AR and Perlman S: Coronaviruses: An overview of their replication and pathogenesis. Methods Mol Biol 1282: 1-23, 2015

24. Phan T: Genetic diversity and evolution of SARS-CoV-2. Infect Genet Evol 81: 104260, 2020

25. Wang Q, Zhang Y, Wu L, Niu S, Song C, Zhang Z, Lu G, Qiao C, $\mathrm{Hu}$ Y, Yuen KY, et al: Structural and functional basis of SARS-CoV-2 entry by using human ACE2. Cell 181: 894-904.e9, 2020.

26. Lan J, Ge J, Yu J, Shan S, Zhou H, Fan S, Zhang Q, Shi X, Wang Q, Zhang L and Wang X: Structure of the SARS-CoV-2 spike receptor-binding domain bound to the ACE2 receptor. Nature 581: 215-220, 2020.

27. Cantuti-Castelvetri L, Ojha R, Pedro LD, Djannatian M, Franz J, Kuivanen S, van der Meer F, Kallio K, Kaya T, Anastasina M, et al: Neuropilin-1 facilitates SARS-CoV-2 cell entry and infectivity. Science 370: 856-860, 2020.

28. Daly JL, Simonetti B, Klein K, Chen KE, Williamson MK, Antón-Plágaro C, Shoemark DK, Simón-Gracia L, Bauer M, Hollandi R, et al: Neuropilin-1 is a host factor for SARS-CoV-2 infection. Science 370: 861-865, 2020

29. Walls AC, Park YJ, Tortorici MA, Wall A, McGuire AT and Veesler D: Structure, function, and antigenicity of the SARS-CoV-2 spike glycoprotein. Cell 181: 281-292.e6, 2020.

30. Su S, Wong G, Shi W, Liu J, Lai ACK, Zhou J, Liu W, Bi Y and Gao GF: Epidemiology, genetic recombination, and pathogenesis of coronaviruses. Trends Microbiol 24: 490-502, 2016

31. Elfiky AA: SARS-CoV-2 RNA dependent RNA polymerase (RdRp) targeting: An in silico perspective. J Biomol Struct Dyn: $1-9,2020$ (Epub ahead of print).

32. Jin Z, Du X, Xu Y, Deng Y, Liu M, Zhao Y, Zhang B, Li X, Zhang L, Peng C, et al: Structure of $\mathrm{M}^{\text {pro }}$ from SARS-CoV-2 and discovery of its inhibitors. Nature 82: 289-293, 2020.

33. Neuman BW, Kiss G, Kunding AH, Bhella D, Baksh MF, Connelly S, Droese B, Klaus JP, Makino S, Sawicki SG, et al: A structural analysis of $\mathrm{M}$ protein in coronavirus assembly and morphology. J Struct Biol 174: 11-22, 2011.

34. Vennema H, Godeke GJ, Rossen JW, Voorhout WF, Horzinek MC, Opstelten DJ and Rottier PJ: Nucleocapsid-independent assembly of coronavirus-like particles by co-expression of viral envelope protein genes. EMBO J 15: 2020-2028, 1996.

35. Escors D, Ortego J, Laude H and Enjuanes L: The membrane M protein carboxy terminus binds to transmissible gastroenteritis coronavirus core and contributes to core stability. J Virol 75: 1312-1324, 2001

36. Bourgonje AR, Abdulle AE, Timens W, Hillebrands JL, Navis GJ, Gordijn SJ, Bolling MC, Dijkstra G, Voors AA, Osterhaus AD, et al: Angiotensin-converting enzyme-2 (ACE2), SARS-CoV-2 and the pathophysiology of coronavirus disease 2019 (COVID-19). J Pathol 251: 228-248, 2020.

37. Zhang H, Penninger JM, Li Y, Zhong N and Slutsky AS Angiotensin-converting enzyme 2 (ACE2) as a SARS-CoV-2 receptor: Molecular mechanisms and potential therapeutic target. Intensive Care Med 46: 586-590, 2020.

38. Castranova V, Rabovsky J, Tucker JH and Miles PR: The alveolar type II epithelial cell: A multifunctional pneumocyte. Toxicol Appl Pharmacol 93: 472-483, 1988.

39. Rockx B, Kuiken T, Herfst S, Bestebroer T, Lamers MM, Oude Munnink BB, de Meulder D, van Amerongen G, van den Brand J, Okba NMA, et al: Comparative pathogenesis of COVID-19, MERS, and SARS in a nonhuman primate model. Science 368: 1012-1015, 2020.

40. Lukassen S, Chua RL, Trefzer T, Kahn NC, Schneider MA, Muley T, Winter H, Meister M, Veith C, Boots AW, et al: SARS-CoV-2 receptor ACE2 and TMPRSS2 are primarily expressed in bronchial transient secretory cells. EMBO J 39: e105114, 2020

41. Chu H, Chan JF, Wang Y, Yuen TT, Chai Y, Hou Y, Shuai H, Yang D, Hu B, Huang X, et al: Comparative replication and immune activation profiles of SARS-CoV-2 and SARS-CoV in human lungs: An ex vivo study with implications for the pathogenesis of COVID-19. Clin Infect Dis 71: 1400-1409, 2020

42. Pachetti M, Marini B, Benedetti F, Giudici F, Mauro E, Storici P, Masciovecchio C, Angeletti S, Ciccozzi M, Gallo RC, et al: Emerging SARS-CoV-2 mutation hot spots include a novel RNA-dependent-RNA polymerase variant. J Transl Med 18: 179, 2020.

43. Holmes EA, O'Connor RC, Perry VH, Tracey I, Wessely S, Arseneault L, Ballard C, Christensen H, Cohen Silver R, Everall I, et al: Multidisciplinary research priorities for the COVID-19 pandemic: A call for action for mental health science. Lancet Psychiatry 7: 547-560, 2020.
44. Roussel Y, Giraud-Gatineau A, Jimeno MT, Rolain JM, Zandotti C, Colson P and Raoult D: SARS-CoV-2: Fear versus data. Int J Antimicrob Agents 55: 105947, 2020.

45. World Health Organization (WHO): WHO Coronavirus Disease (COVID-19) Dashboard. https://covid19.who.int/. Retrieved November 17, 2020

46. Sohrabi C, Alsafi Z, O'Neill N, Khan M, Kerwan A, Al-Jabir A, Iosifidis C and Agha R: World Health Organization declares global emergency: A review of the 2019 novel coronavirus (COVID-19). Int J Surg 76: 71-76, 2020.

47. Bulut $\mathrm{C}$ and Kato Y: Epidemiology of COVID-19. Turk J Med Sci 50: 563-570, 2020.

48. New York City Department of Health and Mental Hygiene (DOHMH) COVID-19 Response Team: Preliminary estimate of excess mortality during the COVID-19 outbreak-New York City, March 11-May 2, 2020. MMWR Morb Mortal Wkly Rep 69: 603-605, 2020.

49. Epidemiology Working Group for NCIP Epidemic Response, Chinese Center for Disease Control and Prevention: The epidemiological characteristics of an outbreak of 2019 novel coronavirus diseases (COVID-19) in China. Zhonghua Liu Xing Bing Xue Za Zhi 41: 145-151, 2020 (In Chinese).

50. Goh KJ, Choong MC, Cheong EH, Kalimuddin S, Duu Wen S, Phua GC, Chan KS and Haja Mohideen S: Rapid progression to acute respiratory distress syndrome: Review of current understanding of critical illness from COVID-19 infection. Ann Acad Med Singap 49: 108-118, 2020.

51. Balasubramanian S, Rao NM, Goenka A, Roderick $M$ and Ramanan AV: Coronavirus Disease 2019 (COVID-19) in children-what we know so far and what we do not? Indian Pediatr 57: 435-442, 2020

52. Zimmermann $\mathrm{P}$ and Curtis $\mathrm{N}$ : Coronavirus infections in children including COVID-19: An overview of the epidemiology, clinical features, diagnosis, treatment and prevention options in children. Pediatr Infect Dis J 39: 355-368, 2020.

53. Sharma G, Volgman AS and Michos ED: Sex differences in mortality from COVID-19 pandemic: Are men vulnerable and women protected? JACC Case Rep 2: 1407-1410, 2020

54. Liu Y, Chen H, Tang K and Guo Y: Clinical manifestations and outcome of SARS-CoV-2 infection during pregnancy. J Infect: Mar 4, 2020 (Epub ahead of print)

55. Rasmussen SA, Smulian JC, Lednicky JA, Wen TS and Jamieson DJ: Coronavirus Disease 2019 (COVID-19) and pregnancy: What obstetricians need to know. Am J Obstet Gynecol 222: 415-426, 2020.

56. Lescure FX, Bouadma L, Nguyen D, Parisey M, Wicky PH, Behillil S, Gaymard A, Bouscambert-Duchamp M, Donati F, Le Hingrat Q, et al: Clinical and virological data of the first cases of COVID-19 in Europe: A case series. Lancet Infect Dis 20: 697-706, 2020.

57. Remuzzi A and Remuzzi G: COVID-19 and Italy: What next? Lancet 395: 1225-1228, 2020.

58. Saglietto A, D'Ascenzo F, Zoccai GB and De Ferrari GM: COVID-19 in Europe: The Italian lesson. Lancet 395: 1110-1111, 2020.

59. COVID-19 Situazione in Italia. http://www.salute.gov. it/portale/nuovocoronavirus/dettaglioContenutiNuovoCoronavirus.jsp?lingua $=$ italiano $\& i d=5351 \&$ are $=$ nuovoCoronavirus $\&$ menu=vuoto. Retrieved May 29, 2020.

60. Saez M, Tobias A, Varga D and Barceló MA: Effectiveness of the measures to flatten the epidemic curve of COVID-19. The case of Spain. Sci Total Environ 727: 138761, 2020

61. Update no. 120. Coronavirus disease (COVID-19). 29.05.2020 https://www.mscbs.gob.es/en/profesionales/saludPublica/ccayes/ alertasActual/nCov/documentos/Actualizacion_120_COVID-19. pdf. Retrieved May 29, 2020.

62. Castaldi S, Romano L, Pariani E, Garbelli C and Biganzoli E: COVID-19: The end of lockdown what next? Acta Biomed 91: 236-238, 2020

63. Mateos R, Fernández M, Franco M and Sánchez M: COVID-19 in Spain. Coming back to the 'new normality' after 2 months of confinement. Int Psychogeriatr 32: 1169-1172, 2020.

64. World Health Organization (WHO): Dashboard Italy From January 29 to 17 November 2020. https://covid19.who. int/region/euro/country/it.

65. World Health Organization (WHO): Dashboard Spain From January 29 to 17 November 2020. https://covid19.who. int/region/euro/country/es.

66. International Monetary Fund Italy. https://www.imf. org/en/Countries/ITA. Retrieved 12 August 12, 2020. 
67. International Monetary Fund Spain. https://www.imf. org/en/Countries/ESP\#countrydata. Retrieved August 12, 2020)

68. Nicola M, Alsafi Z, Sohrabi C, Kerwan A, Al-Jabir A, Iosifidis C, Agha $\mathrm{M}$ and Agha R: The socio-economic implications of the coronavirus pandemic (COVID-19): A review. Int J Surg 78: 185-193, 2020.

69. Rabaan AA, Al-Ahmed SH, Haque S, Sah R, Tiwari R, Malik YS, Dhama K, Yatoo MI, Bonilla-Aldana DK and Rodriguez-Morales AJ: SARS-CoV-2, SARS-CoV, and MERS-COV: A comparative overview. Infez Med 28: 174-184, 2020.

70.Zhou P, Yang XL, Wang XG, Hu B, Zhang L, Zhang W, Si HR, Zhu Y, Li B, Huang CL, et al: A pneumonia outbreak associated with a new coronavirus of probable bat origin. Nature 579: 270-273, 2020.

71. Corman VM, Landt O, Kaiser M, Molenkamp R, Meijer A, Chu DK, Bleicker T, Brünink S, Schneider J, Schmidt ML, et al Detection of 2019 novel coronavirus (2019-nCoV) by real-time RT-PCR. Euro Surveill 25: 2000045, 2020.

72. Chan JF, Yip CC, To KK, Tang TH, Wong SC, Leung KH, Fung AY, Ng AC, Zou Z, Tsoi HW, et al: Improved molecular diagnosis of COVID-19 by the novel, highly sensitive and specific COVID-19-RdRp/Hel Real-Time Reverse Transcription-PCR assay validated in vitro and with clinical specimens. J Clin Microbiol 58: e00310-20, 2020.

73. Artika IM, Wiyatno A and Ma'roef CN: Pathogenic viruses: Molecular detection and characterization. Infect Genet Evol 81: 104215,2020

74. Dai WC, Zhang HW, Yu J, Xu HJ, Chen H, Luo SP, Zhang H, Liang LH, Wu XL, Lei Y and Lin F: CT Imaging and differential diagnosis of COVID-19. Can Assoc Radiol J 71: 195-200, 2020.

75. Adhikari SP, Meng S, Wu YJ, Mao YP, Ye RX, Wang QZ, Sun C, Sylvia S, Rozelle S, Raat $\mathrm{H}$ and Zhou H: Epidemiology, causes, clinical manifestation and diagnosis, prevention and control of coronavirus disease (COVID-19) during the early outbreak period: A scoping review. Infect Dis Poverty 9: 29, 2020

76. Yan Y, Shin WI, Pang YX, Meng Y, Lai J, You C, Zhao H, Lester E, Wu T and Pang CH: The First 75 Days of Nove Coronavirus (SARS-CoV-2) Outbreak: Recent advances, prevention, and treatment. Int J Environ Res Public Health 17: 2323,2020 .

77. Otter JA, Donskey C, Yezli S, Douthwaite S, Goldenberg SD and Weber DJ: Transmission of SARS and MERS coronaviruses and influenza virus in healthcare settings: The possible role of dry surface contamination. J Hosp Infect 92: 235-250, 2016.

78. Dowell SF, Simmerman JM, Erdman DD, Wu JS Chaovavanich A, Javadi M, Yang JY, Anderson LJ, Tong S and Ho MS: Severe acute respiratory syndrome coronavirus on hospital surfaces. Clin Infect Dis 39: 652-657, 2004.

79. Kampf G, Todt D, Pfaender S and Steinmann E: Persistence of coronaviruses on inanimate surfaces and their inactivation with biocidal agents. J Hosp Infect 104: 246-251, 2020

80. World Health Organization (WHO): Novel Coronavirus (2019-nCoV) Advice for the public. WHO, Geneva, 2020.

81. Güner R, Hasanoğlu I and Aktaş F: COVID-19: Prevention and control measures in community. Turk J Med Sci 50: 571-577, 2020.

82. Kwon KT, Ko JH, Shin H, Sung M and Kim JY: Drive-Through screening center for COVID-19: A safe and efficient screening system against massive community outbreak. J Korean Med Sci 35: e123, 2020.

83. Lan L, Xu D, Ye G, Xia C, Wang S, Li Y and Xu H: Positive RT-PCR test results in patients recovered from COVID-19. JAMA 323: 1502-1503, 2020

84. Nikolich-Zugich J, Knox KS, Rios CT, Natt B, Bhattacharya D and Fain MJ: SARS-CoV-2 and COVID-19 in older adults: What we may expect regarding pathogenesis, immune responses, and outcomes. Geroscience 42: 505-514, 2020.

85. Tay MZ, Poh CM, Rénia L, MacAry PA and Ng LFP: The trinity of COVID-19: Immunity, inflammation and intervention. Nat Rev Immunol 20: 363-374, 2020.

86. Shi Y, Wang Y, Shao C, Huang J, Gan J, Huang X, Bucci E, Piacentini M, Ippolito G and Melino G: COVID-19 infection: The perspectives on immune responses. Cell Death Differ 27: 1451-1454, 2020.

87. Ahmadpoor P and Rostaing L: Why the immune system fails to mount an adaptive immune response to a COVID-19 infection. Transpl Int 33: 824-825, 2020
88. Azkur AK, Akdis M, Azkur D, Sokolowska M, van de Veen W, Brüggen MC, O'Mahony L, Gao Y, Nadeau K and Akdis CA Immune response to SARS-CoV-2 and mechanisms of immunopathological changes in COVID-19. Allergy 75: 1564-1581, 2020.

89. de Simone G and Mancusi C: Finding the right time for anti-inflammatory therapy in COVID-19. Int J Infect Dis 101: $247-248,2020$

90. Shah VK, Firmal P, Alam A, Ganguly D and Chattopadhyay S: Overview of immune response during SARS-CoV-2 infection: Lessons from the past. Front Immunol 11: 1949, 2020.

91. Soy M, Keser G, Atagündüz P, Tabak F, Atagündüz I and Kayhan S: Cytokine storm in COVID-19: Pathogenesis and overview of anti-inflammatory agents used in treatment. Clin Rheumatol 39: 2085-2094, 2020.

92. Siddiqi HK and Mehra MR: COVID-19 illness in native and immunosuppressed states: A clinical-therapeutic staging proposal. J Heart Lung Transplant 39: 405-407, 2020.

93. Prompetchara E, Ketloy C and Palaga T: Immune responses in COVID-19 and potential vaccines: Lessons learned from SARS and MERS epidemic. Asian Pac J Allergy Immunol 38: 1-9, 2020.

94. Hadjadj J, Yatim N, Barnabei L, Corneau A, Boussier J, Smith N, Péré H, Charbit B, Bondet V, Chenevier-Gobeaux C, et al: Impaired type I interferon activity and exacerbated inflammatory responses in severe COVID-19 patients. Science 369: 718-724, 2020

95. Tufan A, Avanoğlu Güler A and Matucci-Cerinic M: COVID-19, immune system response, hyperinflammation and repurposing antirheumatic drugs. Turk J Med Sci 50(SI-1): 620-632, 2020.

96. Gubernatorova EO, Gorshkova EA, Polinova AI and Drutskaya MD: IL-6: Relevance for immunopathology of SARS-CoV-2. Cytokine Growth Factor Rev 53: 13-24, 2020.

97. Xu Z, Shi L, Wang Y, Zhang J, Huang L, Zhang C, Liu S, Zhao P, Liu H, Zhu L, et al: Pathological findings of COVID-19 associated with acute respiratory distress syndrome. Lancet Respir Med 8: 420-422, 2020

98.Zhang B, Zhou X, Qiu Y, Song Y, Feng F, Feng J, Song Q, Jia Q and Wang J: Clinical characteristics of 82 cases of death with COVID-19. PLoS One 15: e0235458, 2020

99. He R, Lu Z, Zhang L, Fan T, Xiong R, Shen X, Feng H, Meng H, Lin W, Jiang W and Geng Q: The clinical course and its correlated immune status in COVID-19 pneumonia. J Clin Virol 127: 104361,2020

100. Coperchini F, Chiovato L, Croce L, Magri F and Rotondi M: The cytokine storm in COVID-19: An overview of the involvement of the chemokine/chemokine-receptor system. Cytokine Growth Factor Rev 53: 25-32, 2020.

101. Ye Q, Wang B and Mao J: The pathogenesis and treatment of the 'Cytokine Storm' in COVID-19. J Infect 80: 607-613, 2020.

102. Li H, Liu L, Zhang D, Xu J, Dai H, Tang N, Su X and Cao B SARS-CoV-2 and viral sepsis: Observations and hypotheses. Lancet 395: 1517-1520, 2020.

103. Li X and Ma X: Acute respiratory failure in COVID-19: Is it 'typical' ARDS? Crit Care 24: 198, 2020.

104. Hand TW, Vujkovic-Cvijin I, Ridaura VK and Belkaid Y: Linking the microbiota, chronic disease, and the immune system. Trends Endocrinol Metab 27: 831-843, 2016.

105. Stoian AP, Banerjee Y, Rizvi AA and Rizzo M: Diabetes and the COVID-19 pandemic: How insights from recent experience might guide future management. Metab Syndr Relat Disord 18: 173-175, 2020.

106. Dietz W and Santos-Burgoa C: Obesity and its implications for COVID-19 mortality. Obesity (Silver Spring) 28: 1005, 2020.

107. Ryan PM and Caplice NM: Is adipose tissue a reservoir for viral spread, immune activation and cytokine amplification in Coronavirus Disease 2019? Obesity (Silver Spring) 8: 1191-1194, 2020.

108. Nikolich-Žugich J: The twilight of immunity: Emerging concepts in aging of the immune system. Nat Immunol 19: 10-19, 2018.

109. Butler MJ and Barrientos RM: The impact of nutrition on COVID-19 susceptibility and long-term consequences. Brain Behav Immun 87: 53-54, 2020.

110. Körner A, Schlegel M, Theurer J, Frohnmeyer H, Adolph M, Heijink M, Giera M, Rosenberger P and Mirakaj V: Resolution of inflammation and sepsis survival are improved by dietary $\Omega-3$ fatty acids. Cell Death Differ 25: 421-431, 2018.

111. Panigrahy D, Gilligan MM, Huang S, Gartung A, Cortés-Puch I, Sime PJ, Phipps RP, Serhan CN and Hammock BD: Inflammation resolution: A dual-pronged approach to averting cytokine storms in COVID-19? Cancer Metastasis Rev 39: 337-340, 2020. 
112. Chen P, Mao L, Nassis GP, Harmer P, Ainsworth BE and Li F: Coronavirus disease (COVID-19): The need to maintain regular physical activity while taking precautions. J Sport Health Sci 9: 103-104, 2020.

113. Sardu C, Gambardella J, Morelli MB, Wang X, Marfella R and Santulli G: Hypertension, thrombosis, kidney failure, and diabetes: Is COVID-19 an endothelial disease? A comprehensive evaluation of clinical and basic evidence. J Clin Med 9: E1417, 2020

114. Guzik TJ, Mohiddin SA, Dimarco A, Patel V, Savvatis K, Marelli-Berg FM, Madhur MS, Tomaszewski M, Maffia P, D'Acquisto F, et al: COVID-19 and the cardiovascular system: Implications for risk assessment, diagnosis, and treatment options. Cardiovasc Res 116: 1666-1687, 2020.

115. Hamming I, Timens W, Bulthuis ML, Lely AT, Navis G and van Goor $\mathrm{H}$ : Tissue distribution of ACE2 protein, the functional receptor for SARS coronavirus. A first step in understanding SARS pathogenesis. J Pathol 203: 631-637, 2004.

116. Varga Z, Flammer AJ, Steiger P, Haberecker M, Andermatt R, Zinkernagel AS, Mehra MR, Schuepbach RA, Ruschitzka F and Moch H: Endothelial cell infection and endotheliitis in COVID-19. Lancet 395: 1417-1418, 2020.

117. Alvarado-Moreno JA and Majluf-Cruz A: COVID-19 and dysfunctional endothelium: The Mexican Scenario. Arch Med Res 51: 587-588, 2020.

118. Zhou X, Zhu J and Xu T: Clinical characteristics of coronavirus disease 2019 (COVID-19) patients with hypertension on renin-angiotensin system inhibitors. Clin Exp Hypertens 42 : 656-660, 2020.

119. Bikdeli B, Madhavan MV, Jimenez D, Chuich T, Dreyfus I, Driggin E, Nigoghossian C, Ageno W, Madjid M, Guo Y, et al: COVID-19 and thrombotic or thromboembolic disease Implications for prevention, antithrombotic therapy, and follow-up: JACC State-of-the-Art Review. J Am Coll Cardiol 75 2950-2973, 2020

120.von Brühl ML, Stark K, Steinhart A, Chandraratne S, Konrad I, Lorenz M, Khandoga A, Tirniceriu A, Coletti R, Köllnberger M, et al: Monocytes, neutrophils, and platelets cooperate to initiate and propagate venous thrombosis in mice in vivo. J Exp Med 209: 819-835, 2012.

121. Gunzer M: Escaping the traps of your own hunters. Science 358 1126-1127, 2017.

122. de Bont CM, Boelens WC and Pruijn GJM: NETosis, complement, and coagulation: A triangular relationship. Cell Mol Immunol 16: 19-27, 2019.

123. Merad M and Martin JC: Pathological inflammation in patients with COVID-19: A key role for monocytes and macrophages. Nat Rev Immunol 20: 355-362, 2020.

124. Massberg S, Grahl L, von Bruehl ML, Manukyan D, Pfeiler S, Goosmann C, Brinkmann V, Lorenz M, Bidzhekov K, Khandagale $\mathrm{AB}$, et al: Reciprocal coupling of coagulation and innate immunity via neutrophil serine proteases. Nat Med 16 $887-896,2010$.

125. Oehmcke S, Mörgelin M and Herwald H: Activation of the human contact system on neutrophil extracellular traps. J Innate Immun 1: 225-230, 2009.

126. Semeraro F, Ammollo CT, Morrissey JH, Dale GL, Friese P, Esmon NL and Esmon CT: Extracellular histones promote thrombin generation through platelet-dependent mechanisms: Involvement of platelet TLR2 and TLR4. Blood 118: 1952-1961, 2011

127. Jiménez-Alcázar M, Rangaswamy $\mathrm{C}$, Panda R, Bitterling J, Simsek YJ, Long AT, Bilyy R, Krenn V, Renné C, Renné T, et al Host DNases prevent vascular occlusion by neutrophil extracellular traps. Science 358: 1202-1206, 2017.

128. Lee KH, Cavanaugh L, Leung H, Yan F, Ahmadi Z, Chong BH and Passam F: Quantification of NETs-associated markers by flow cytometry and serum assays in patients with thrombosis and sepsis. Int J Lab Hematol 40: 392-399, 2018.

129. Barnes BJ, Adrover JM, Baxter-Stoltzfus A, Borczuk A, Cools-Lartigue J, Crawford JM, Daßler-Plenker J, Guerci P, Huynh C, Knight JS, et al: Targeting potential drivers of COVID-19: Neutrophil extracellular traps. J Exp Med 217 e20200652, 2020

130. Zhang Y, Xiao M, Zhang S, Xia P, Cao W, Jiang W, Chen H, Ding $\mathrm{X}$, Zhao $\mathrm{H}$, Zhang $\mathrm{H}$, et al: Coagulopathy and antiphospholipid antibodies in patients with covid-19. N Engl J Med 382: e38,2020.

131. Escher R, Breakey N and Lämmle B: Severe COVID-19 infection associated with endothelial activation. Thromb Res 190: 62, 2020 .
132. Whyte CS, Morrow GB, Mitchell JL, Chowdary P and Mutch NJ: Fibrinolytic abnormalities in acute respiratory distress syndrome (ARDS) and versatility of thrombolytic drugs to treat COVID-19. J Thromb Haemost 18: 1548-1555, 2020.

133. Zhu J, Zhong Z, Ji P, Li H, Li B, Pang J, Zhang J and Zhao C: Clinicopathological characteristics of 8697 patients with COVID-19 in China: A meta-analysis. Fam Med Community Health 8: e000406, 2020.

134. Novel Coronavirus-China. www.who.int/csr/don/12-january2020-novel-coronavirus-china/en/. Retrieved May 30, 2020.

135. Song Z, Xu Y, Bao L, Zhang L, Yu P, Qu Y, Zhu H, Zhao W, Han Y and Qin C: From SARS to MERS, thrusting coronaviruses into the spotlight. Viruses 11: 59, 2019.

136. Fu J, Zhou B, Zhang L, Balaji KS, Wei C, Liu X, Chen H, Peng $\mathrm{J}$ and $\mathrm{Fu} \mathrm{J}$ : Expressions and significances of the angiotensin-converting enzyme 2 gene, the receptor of SARS-CoV-2 for COVID-19. Mol Biol Rep 47: 4383-4392, 2020.

137. Hui KPY, Cheung MC, Perera RAPM, Ng KC, Bui CHT, Ho JCW, Ng MMT, Kuok DIT, Shih KC, Tsao SW, et al: Tropism, replication competence, and innate immune responses of the coronavirus SARS-CoV-2 in human respiratory tract and conjunctiva: An analysis in ex-vivo and in-vitro cultures. Lancet Respir Med 8: 687-695, 2020.

138. Xu H, Zhong L, Deng J, Peng J, Dan H, Zeng X, Li T and Chen Q: High expression of ACE2 receptor of 2019-nCoV on the epithelial cells of oral mucosa. Int J Oral Sci 12: 8, 2020

139. Zhang H, Kang Z, Gong H, Xu D, Wang J, Li Z, Li Z, Cui X, Xiao J, Zhan J, et al: Digestive system is a potential route of COVID-19: An analysis of single-cell coexpression pattern of key proteins in viral entry process. Gut 69: 1010-1018, 2020.

140. Gao Y, Li T, Han M, Li X, Wu D, Xu Y, Zhu Y, Liu Y, Wang X and Wang L: Diagnostic utility of clinical laboratory data determinations for patients with the severe COVID-19. J Med Virol 92: 791-796, 2020.

141. Wang Y, Kang H, Liu X and Tong Z: Asymptomatic cases with SARS-CoV-2 infection. J Med Virol 92: 1401-1403, 2020.

142. Fu L, Wang B, Yuan T, Chen X, Ao Y, Fitzpatrick T, Li P, Zhou Y, Lin YF, Duan Q, et al: Clinical characteristics of coronavirus disease 2019 (COVID-19) in China: A systematic review and meta-analysis. J Infect 80: 656-665, 2020

143. Lian J, Jin X, Hao S, Jia H, Cai H, Zhang X, Hu J, Zheng L, Wang X, Zhang S, et al: Epidemiological, clinical, and virological characteristics of 465 hospitalized cases of coronavirus disease 2019 (COVID-19) from Zhejiang province in China. Influenza Other Respir Viruses 14: 564-574, 2020.

144. Gattinoni L, Chiumello D, Caironi P, Busana M, Romitti F, Brazzi L and Camporota L: COVID-19 pneumonia: Different respiratory treatments for different phenotypes? Intensive Care Med 46: 1099-1102, 2020.

145. The European Society for Cardiology (ESC): ESC Guidance for the Diagnosis and Management of CV Disease during the COVID-19 Pandemic. https://www.escardio.org/Educatio n/COVID-19-and-Cardiology/ESCCOVID-19-Guidance. Last updated May 28, 2020)

146. Shang W, Dong J, Ren Y, Tian M, Li W, Hu J and Li Y: The value of clinical parameters in predicting the severity of COVID-19. J Med Virol 92: 2188-2192, 2020.

147. Cai Q, Chen F, Wang T, Luo F, Liu X, Wu Q, He Q, Wang Z, Liu Y, Liu L, et al: Obesity and COVID-19 Severity in a Designated Hospital in Shenzhen, China. Diabetes Care 43: 1392-1398, 2020.

148. Palaiodimos L, Kokkinidis DG, Li W, Karamanis D, Ognibene J, Arora S, Southern WN and Mantzoros CS: Severe obesity, increasing age and male sex are independently associated with worse in-hospital outcomes, and higher in-hospital mortality, in a cohort of patients with COVID-19 in the Bronx, New York. Metabolism 108: 154262, 2020.

149. Zhang L, Feng X, Zhang D, Jiang C, Mei H, Wang J, Zhang C, $\mathrm{Li} \mathrm{H}, \mathrm{Xia} \mathrm{X}$, Kong S, et al: Deep vein thrombosis in hospitalized patients with (COVID-19) in Wuhan, China: Prevalence, risk factors, and outcome. Circulation 142: 114-128, 2020.

150. Stoneham SM, Milne KM, Nuttall E, Frew GH, Sturrock BR, Sivaloganathan H, Ladikou EE, Drage S, Phillips B, Chevassut TJ and Eziefula AC: Thrombotic risk in COVID-19: A case series and case-control study. Clin Med (Lond) 20: e76-e81, 2020.

151. Jin X, Lian JS, Hu JH, Gao J, Zheng L, Zhang YM, Hao SR, Jia HY, Cai H, Zhang XL, et al: Epidemiological, clinical and virological characteristics of 74 cases of coronavirus-infected disease 2019 (COVID-19) with gastrointestinal symptoms. Gut 69: 1002-1009, 2020. 
152. Lin L, Jiang X, Zhang Z, Huang S, Zhang Z, Fang Z, Gu Z, Gao L, Shi H, Mai L, et al: Gastrointestinal symptoms of 95 cases with SARS-CoV-2 infection. Gut 69: 997-1001, 2020

153. Mao R, Qiu Y, He JS, Tan JY, Li XH, Liang J, Shen J, Zhu LR, Chen Y, Iacucci M, et al: Manifestations and prognosis of gastrointestinal and liver involvement in patients with COVID-19: A systematic review and meta-analysis. Lancet Gastroenterol Hepatol 5: 667-678, 2020.

154. To KK, Tsang OT, Yip CC, Chan KH, Wu TC, Chan JM, Leung WS, Chik TS, Choi CY, Kandamby DH, et al: Consistent detection of 2019 novel coronavirus in saliva. Clin Infect Dis 71: 841-843, 2020.

155. Holshue ML, DeBolt C, Lindquist S, Lofy KH, Wiesman J, Bruce H, Spitters C, Ericson K, Wilkerson S, Tural A, et al: First Case of 2019 Novel Coronavirus in the United States. N Engl J Med 382: 929-936, 2020

156. Zhou F, Yu T, Du R, Fan G, Liu Y, Liu Z, Xiang J, Wang Y, Song $\mathrm{B}, \mathrm{Gu} \mathrm{X}$, et al: Clinical course and risk factors for mortality of adult inpatients with COVID-19 in Wuhan, China: A retrospective cohort study. Lancet 395: 1054-1062, 2020.

157. Jiang SQ, Huang QF, Xie WM, Lv C and Quan XQ: The association between severe COVID-19 and low platelet count: Evidence from 31 observational studies involving 7613 participants. $\mathrm{Br}$ J Haematol 190: e29-e33, 2020.

158. Doobay MF, Talman LS, Obr TD, Tian X, Davisson RL and Lazartigues E: Differential expression of neuronal ACE2 in transgenic mice with overexpression of the brain renin-angiotensin system. Am J Physiol Regul Integr Comp Physiol 292: R373-R381, 2007.

159. Liguori C, Pierantozzi M, Spanetta M, Sarmati L, Cesta N, Iannetta M, Ora J, Mina GG, Puxeddu E, Balbi O, et al Subjective neurological symptoms frequently occur in patients with SARS-CoV2 infection. Brain Behav Immun 88: 11-16, 2020.

160. Kim GU, Kim MJ, Ra SH, Lee J, Bae S, Jung J and Kim SH: Clinical characteristics of asymptomatic and symptomatic patients with mild COVID-19. Clin Microbiol Infect 26: 948. e1-948.e3, 2020.

161. Ye M, Ren Y and Lv T: Encephalitis as a clinical manifestation of COVID-19. Brain Behav Immun 88: 945-946, 2020.

162. Bernard-Valnet R, Pizzarotti B, Anichini A, Demars Y, Russo E, Schmidhauser M, Cerutti-Sola J, Rossetti AO and Du Pasquier R: Two patients with acute meningoencephalitis concomitant to SARS-CoV-2 infection. Eur J Neurol 27: e43-e44, 2020.

163. Moriguchi T, Harii N, Goto J, Harada D, Sugawara H, Takamino J, Ueno M, Sakata H, Kondo K, Myose N, et al: A first case of meningitis/encephalitis associated with SARS-Coronavirus-2. Int J Infect Dis 94: 55-58, 2020

164. Pei G, Zhang Z, Peng J, Liu L, Zhang C, Yu C, Ma Z, Huang Y, Liu W, Yao Y, et al: Renal involvement and early prognosis in patients with COVID-19 pneumonia. J Am Soc Nephrol 31: $1157-1165,2020$.

165. Galván Casas C, Català A, Carretero Hernández G, Rodríguez-Jiménez P,Fernández Nieto D, Rodríguez-Villa Lario A, Navarro Fernández I, Ruiz-Villaverde R, Falkenhain-López D, Llamas Velasco M, et al: Classification of the cutaneous manifestations of COVID-19: A rapid prospective nationwide consensus study in Spain with 375 cases. Br J Dermatol 183: 71-77, 2020.

166. Tang K, Wang Y, Zhang H, Zheng Q, Fang R and Sun Q Cutaneous manifestations of the Coronavirus Disease 2019 (COVID-19): A brief review. Dermatol Ther 33: e13528, 2020.

167. Chen L, Deng C, Chen X, Zhang X, Chen B, Yu H, Qin Y, Xiao K, Zhang $H$ and Sun X: Ocular manifestations and clinical characteristics of 535 cases of COVID-19 in Wuhan, China: a cross-sectional study. Acta Ophthalmol 98: e951e959, 2020.

168. Loffredo L, Pacella F, Pacella E, Tiscione G, Oliva A and Violi F: Conjunctivitis and COVID-19: A meta-analysis. J Med Virol 92: 1413-1414, 2020

169. Panahi L, Amiri M and Pouy S: Clinical characteristics of COVID-19 infection in newborns and pediatrics: A systematic review. Arch Acad Emerg Med 8: e50, 2020.

170. Mustafa NM and A Selim L: Characterisation of COVID-19 Pandemic in Paediatric Age Group: A systematic review and meta-analysis. J Clin Virol 128: 104395, 2020.

171. Liguoro I, Pilotto C, Bonanni M, Ferrari ME, Pusiol A, Nocerino A, Vidal E and Cogo P: SARS-COV-2 infection in children and newborns: A systematic review. Eur J Pediatr 179: 1029-1046, 2020.
172. Sun D, Li H, Lu XX, Xiao H, Ren J, Zhang FR and Liu ZS: Clinical features of severe pediatric patients with coronavirus disease 2019 in Wuhan: A single center's observational study. World J Pediatr 16: 251-259, 2020

173. Juan J, Gil MM, Rong Z, Zhang Y, Yang H and Poon LC: Effects of coronavirus disease 2019 (COVID-19) on maternal, perinatal and neonatal outcomes: A systematic review. Ultrasound Obstet Gynecol 56: 15-27, 2020.

174. Alzamora MC, Paredes T, Caceres D, Webb CM, Valdez LM and La Rosa M: Severe COVID-19 during pregnancy and possible vertical transmission. Am J Perinatol 37: 861-865, 2020.

175. Valdés G, Neves LA, Anton L, Corthorn J, Chacón C, Germain AM, Merrill DC, Ferrario CM, Sarao R, Penninger J and Brosnihan KB: Distribution of angiotensin-(1-7) and ACE2 in human placentas of normal and pathological pregnancies. Placenta 27: 200-207, 2006.

176. Spanish Ministry: Available treatments subjected to special access conditions for the managing of the respiratory infection by SARS-CoV-2. Spanish Agency for Medicines and Health Products, 2020. https://www.aemps.gob. es/la-aemps/ultima-informacion-de-la-aemps-acerca-del-cov id\%E2\%80\%9119/tratamientos-disponibles-para-el-manejo-de -la-infeccion-respiratoria-por-sars-cov-2/?lang=en. Retrieved May 28, 2020,

177. World Health Organization (WHO): Clinical management of COVID-19: interim guidance. https://apps.who. int/iris/handle/10665/332196. License: CC BY-NC-SA 3.0 IGO. Accessed May 27, 2020.

178. Wu R, Wang L, Kuo HD, Shannar A, Peter R, Chou PJ, Li S, Hudlikar R, Liu X, Liu Z, et al: An update on current therapeutic drugs treating COVID-19. Curr Pharmacol Rep: May 11, 2020 (Epub ahead for print)

179. Zhou M, Zhang X and Qu J: Coronavirus disease 2019 (COVID-19): A clinical update. Front Med 14: 126-135, 2020

180. Dima A, Balaban DV, Jurcut C, Berza I, Jurcut R and Jinga M: Physicians' Perspectives on COVID-19: An International Survey. Healthcare (Basel) 8: 250, 2020

181. Jawhara S: Could intravenous immunoglobulin collected from recovered coronavirus patients protect against COVID-19 and strengthen the immune system of new patients? Int J Mol Sci 21: $2272,2020$.

182. Qiu T, Liang S, Dabbous M, Wang Y, Han R and Toumi M: Chinese guidelines related to novel coronavirus pneumonia. J Mark Access Health Policy 8: 1818446, 2020.

183. Gutiérrez-Lorenzo M and Cuadros-Martínez CM: Baricitinib in treatment of SARS-CoV-2 infection. Rev Esp Quimioter 33 294-295, 2020 (In Spanish).

184. Singh AK, Majumdar S, Singh R and Misra A: Role of corticosteroid in the management of COVID-19: A systemic review and a Clinician's perspective. Diabetes Metab Syndr 14: 971-978, 2020

185. Mulangu S, Dodd LE, Davey RT Jr, Tshiani Mbaya O, Proschan M, Mukadi D, Lusakibanza Manzo M, Nzolo D, Tshomba Oloma A, Ibanda A, et al: A randomized, controlled trial of Ebola virus disease therapeutics. N Engl J Med 381: 2293-2303, 2019.

186. de Wit E, Feldmann F, Cronin J, Jordan R, Okumura A, Thomas T, Scott D, Cihlar T and Feldmann H: Prophylactic and therapeutic remdesivir (GS-5734) treatment in the rhesus macaque model of MERS-CoV infection. Proc Natl Acad Sci USA 117: 6771-6776, 2020.

187. Lo MK, Feldmann F, Gary JM, Jordan R, Bannister R, Cronin J, Patel NR, Klena JD, Nichol ST, Cihlar T, et al: Remdesivir (GS-5734) protects African green monkeys from Nipah virus challenge. Sci Transl Med 11: eaau9242, 2019.

188. Grein J, Ohmagari N, Shin D, Diaz G, Asperges E, Castagna A, Feldt T, Green G, Green ML, Lescure FX, et al: Compassionate use of remdesivir for patients with severe Covid-19. N Engl J Med 382: 2327-2336, 2020

189. Ferner RE and Aronson JK: Remdesivir in covid-19. BMJ m1610: 369,2020

190. Jean SS, Lee PI and Hsueh PR: Treatment options for COVID-19: The reality and challenges. J Microbiol Immunol Infect 53 436-443, 2020.

191. Groneberg DA, Poutanen SM, Low DE, Lode H, Welte T and Zabel P: Treatment and vaccines for severe acute respiratory syndrome. Lancet Infect Dis 5: 147-155, 2005.

192. Cao B, Wang Y, Wen D, Liu W, Wang J, Fan G, Ruan L, Song B, Cai Y, Wei M, et al: A Trial of Lopinavir-Ritonavir in Adults Hospitalized with Severe Covid-19. N Engl J Med 382: 1787-1799, 2020. 
193. Kunz KM: A Trial of Lopinavir-Ritonavir in Covid-19. N Engl J Med 382: e68, 2020.

194. Statement from the Chief Investigators of the Randomised Evaluation of COVid-19 thERapY (RECOVERY) Trial on lopinavir-ritonavir. https://www.recoverytrial.net/files/lopinavir-ritonavir-recovery-statement-29062020_final.pdf.Accessed June 29, 2020

195. Al-Bari MA: Chloroquine analogues in drug discovery: New directions of uses, mechanisms of actions and toxic manifestations from malaria to multifarious diseases. J Antimicrob Chemother 70: 1608-1621, 2015.

196. Vincent MJ, Bergeron E, Benjannet S, Erickson BR, Rollin PE, Ksiazek TG, Seidah NG and Nichol ST: Chloroquine is a potent inhibitor of SARS coronavirus infection and spread. Virol J 2: 69,2005

197. Wang M, Cao R, Zhang L, Yang X, Liu J, Xu M, Shi Z, Hu Z, Zhong W and Xiao G: Remdesivir and chloroquine effectively inhibit the recently emerged novel coronavirus $(2019-\mathrm{nCoV})$ in vitro. Cell Res 30: 269-271, 2020.

198. Andreani J, Le Bideau M, Duflot I, Jardot P, Rolland C, Boxberger M, Wurtz N, Rolain JM, Colson P, La Scola B and Raoult D: In vitro testing of combined hydroxychloroquine and azithromycin on SARS-CoV-2 shows synergistic effect. Microb Pathog 145: 104228, 2020.

199. Gautret P, Lagier JC, Parola P, Hoang V, Meddeb L, Mailhe M, Doudier B, Courjon J, Giordanengo V, Vieira V, et al: Hydroxychloroquine and azithromycin as a treatment of COVID-19: Results of an open- label non-randomized clinical trial. Int J Antimicrob Agents 56: 105949, 2020.

200. Molina JM, Delaugerre C, Goff JL, Mela-Lima B, Ponscarme D, Goldwirt L and de Castro N: No evidence of rapid antiviral clearance or clinical benefit with the combination of hydroxychloroquine and azithromycin in patients with severe COVID-19 infection. Med Mal Infect 50: 384, 2020.

201. Rosenberg ES, Dufort EM, Udo T, Wilberschied LA, Kumar J, Tesoriero J, Weinberg P, Kirkwood J, Muse A, DeHovitz J, et al: Association of treatment with hydroxychloroquine or azithromycin with in-hospital mortality in patients with COVID-19 in New York State. JAMA 323: 2493-2502, 2020.

202. Hornby P and Landray M: Statement from the Chief Investigators of the Randomised Evaluation of COVid-19 thERapY (RECOVERY) Trial on hydroxychloroquine.https://www.recoverytrial.net/files/hcq-recovery-statement-050620-final-002.pdf. Accessed June 5, 2020.

203. Mansourabadi AH, Sadeghalvad M, Mohammadi-Motlagh HR and Rezaei N: The immune system as a target for therapy of SARS-CoV-2: A systematic review of the current immunotherapies for COVID-19. Life Sci 258: 118185, 2020.

204.Aouba A, Baldolli A, Geffray L, Verdon R, Bergot E, Martin-Silva $\mathrm{N}$ and Justet A: Targeting the inflammatory cascade with anakinra in moderate to severe COVID-19 pneumonia: Case series. Ann Rheum Dis 79: 1381-1382, 2020.

205. Zhang C, Wu Z, Li JW, Zhao H and Wang GQ: Cytokine release syndrome in severe COVID-19: Interleukin-6 receptor antagonist Tocilizumab may be the key to reduce the mortality. Int J Antimicrob Agents 55: 105954, 2020.

206. Sheppard M, Laskou F, Stapleton PP, Hadavi S and Dasgupta B: Tocilizumab (Actemra). Hum Vaccin Immunother 13: 1972-1988, 2017.

207. Vastert SJ, Jamilloux Y, Quartier P, Ohlman S, Osterling Koskinen L, Kullenberg T, Franck-Larsson K, Fautrel B and de Benedetti F: Anakinra in children and adults with Still's disease. Rheumatology (Oxford) 58 (Suppl 6): vi9-vi22, 2018.

208. Guaraldi G, Meschiari M, Cozzi-Lepri A, Milic J, Tonelli R, Menozzi M, Franceschini E, Cuomo G, Orlando G, Borghi V, et al: Tocilizumab in patients with severe COVID-19: A retrospective cohort study. Lancet Rheumatol 2: e474-e484, 2020.

209. Tomasiewicz K, Piekarska A, Stempkowska-Rejek J, Serafińska S, Gawkowska A, Parczewski M,Niścigorska-Olsen J, Łapiński TW, Zarębska-Michaluk D, Kowalska JD, et al Tocilizumab for patients with severe COVID-19: A retrospective, multi-center study. Expert Rev Anti Infect Ther: Aug 1, 2020 (Epub ahead of print).

210. Cauchois R, Koubi M, Delarbre D, Manet C, Carvelli J, Blasco VB, Jean R, Fouche L, Bornet C, Pauly V, et al: Early IL-1 receptor blockade in severe inflammatory respiratory failure complicating COVID-19. Proc Natl Acad Sci USA 117 18951-18953, 2020.
211. McGonagle D, Sharif K, O'Regan A and Bridgewood C: The role of cytokines including interleukin-6 in COVID-19 induced pneumonia and macrophage activation syndrome-like disease. Autoimmun Rev 19: 102537, 2020.

212. Xu X, Han M, Li T, Sun W, Wang D, Fu B, Zhou Y, Zheng X, Yang Y, Li X, et al: Effective treatment of severe COVID-19 patients with tocilizumab. Proc Natl Acad Sci USA 117: 10970-10975, 2020

213. Alzghari SK and Acuña VS: Supportive treatment with tocilizumab for COVID-19: A systematic review. J Clin Virol 127: 104380,2020

214. Galimberti S, Baldini C, Baratè C, Ricci F, Balducci S, Grassi S, Ferro F, Buda G, Benedetti E, Fazzi R, et al: The CoV-2 outbreak: How hematologists could help to fight Covid-19. Pharmacol Res 157: 104866, 2020.

215. Peterson D, Damsky W and King B: The use of Janus kinase inhibitors in the time of severe acute respiratory syndrome coronavirus 2 (SARS-CoV-2). J Am Acad Dermatol 82: e223-e226, 2020.

216. Chang R, Ng TB and Sun WZ: Lactoferrin as potential preventative and adjunct treatment for COVID-19. Int J Antimicrob Agents 56: 106118, 2020.

217. Ucciferri C, Barone M, Vecchiet J and Falasca K: Pidotimod in paucisymptomatic SARS-CoV2 infected patients. Mediterr J Hematol Infect Dis 12: e2020048, 2020.

218. Colunga Biancatelli RML, Berrill M, Catravas JD and Marik PE: Quercetin and vitamin C: An experimental, synergistic therapy for the prevention and treatment of SARS-CoV-2 related disease (COVID-19). Front Immunol 11: 1451, 2020.

219. Mettenleiter TC: Chapter One-The First 'Virus Hunters' In: Advances in Virus Research. Beer M and Höper D (eds). Academic Press, pp1-16, 2017.

220. Goldsmith CS and Miller SE: Modern uses of electron microscopy for detection of viruses. Clin Microbiol Rev 22: 552-563, 2009.

221. Singh L, Kruger HG, Maguire GEM, Govender T and Parboosing R: The role of nanotechnology in the treatment of viral infections. Ther Adv Infect Dis 4: 105-131, 2017.

222. Sivasankarapillai VS, Pillai AM, Rahdar A, Sobha AP, Das SS, Mitropoulos AC, Mokarrar MH and Kyzas GZ: On facing the SARS-CoV-2 (COVID-19) with combination of nanomaterials and medicine: Possible strategies and first challenges. Nanomaterials (Basel) 10: 852, 2020.

223. Kostarelos K: Nanoscale nights of COVID-19. Nat Nanotechnol 15: 343-344, 2020.

224.Patra JK, Das G, Fraceto LF, Campos EVR, Rodriguez-Torres MDP, Acosta-Torres LS, Diaz-Torres LA, Grillo R, Swamy MK, Sharma S, et al: Nano based drug delivery systems: Recent developments and future prospects. J Nanobiotechnology 16: 71, 2018.

225. Chen L and Liang J: An overview of functional nanoparticles as novel emerging antiviral therapeutic agents. Mater Sci Eng C Mater Biol Appl 112: 110924, 2020.

226. Cui H, Webber MJ and Stupp SI: Self-assembly of peptide amphiphiles: From molecules to nanostructures to biomaterials. Biopolymers 94: 1-18, 2010.

227. Dormont F, Brusini R, Cailleau C, Reynaud F, Peramo A Gendron A, Mougin J, Gaudin F, Varna M and Couvreur P. Squalene-based multidrug nanoparticles for improved mitigation of uncontrolled inflammation. Sci Adv 6: eaaz5466, 2020.

228. Hu Y, Liu C and Muyldermans S: Nanobody-based delivery systems for diagnosis and targeted tumor therapy. Front Immunol 8: 1442, 2017.

229. Walter JD, Hutter CAJ, Zimmermann I, Earp J, Egloff P, Sorgenfrei M, Hürlimann LM, Gonda I, Meier G, Remm S, et al: Synthetic nanobodies targeting the SARS-CoV-2 receptor-binding domain. BioRxiv: 1-18, 2020

230. Ura T, Okuda K and Shimada M: Developments in viral vector-based vaccines. Vaccines (Basel) 2: 624-641, 2014.

231. $\mathrm{Xu} \mathrm{H}, \mathrm{Li} \mathrm{Z}$ and $\mathrm{Si} \mathrm{J}$ : Nanocarriers in gene therapy: A review. J Biomed Nanotechnol 10: 3483-3507, 2014

232. Feldman RA, Fuhr R, Smolenov I, Ribeiro A, Panther L, Watson M, Senn JJ, Smith M, Almarsson Ö, Pujar HS, et al: mRNA vaccines against H10N8 and H7N9 influenza viruses of pandemic potential are immunogenic and well tolerated in healthy adults in phase 1 randomized clinical trials. Vaccine 37: 3326-3334, 2019.

233. McKay PF, Hu K, Blakney AK, Samnuan K, Bouton CR, Rogers P, Polra K, Lin PJC, Barbosa C, Tam Y and Shattock RJ: Self-amplifying RNA SARS-CoV-2 lipid nanoparticle vaccine induces equivalent preclinical antibody titers and viral neutralization to recovered COVID-19 patients. doi: https://doi. org/10.1101/2020.04.22.055608 
234. Raghunandan R, Lu H, Zhou B, Xabier MG, Massare MJ Flyer DC, Fries LF, Smith GE and Glenn GM: An insect cell derived respiratory syncytial virus (RSV) F nanoparticle vaccine induces antigenic site II antibodies and protects against RSV challenge in cotton rats by active and passive immunization. Vaccine 32: 6485-6492, 2014.

235. He L, de Val N, Morris CD, Vora N, Thinnes TC, Kong L, Azadnia P, Sok D, Zhou B, Burton DR, et al: Presenting native-like trimeric HIV-1 antigens with self-assembling nanoparticles. Nat Commun 7: 12041, 2016.

236. Foundation TWN. COVID-19 testing report \& analysis, 2020 https://www.worldnanofoundation.com/covid-19-report-analysis. Accessed July 24, 2020.

237. Zhao Z, Cui H, Song W, Ru X, Zhou W and Yu X: A simple magnetic nanoparticles-based viral RNA extraction method for efficient detection of SARS-CoV-2. bioRxiv: doi: https://doi. org/10.1101/2020.02.22.961268.
238. Wang M, Fu A, Hu B, Tong Y, Liu R, Liu Z, Gu J, Xiang B, Liu J, Jiang W, et al: Nanopore target sequencing for accurate and comprehensive detection of SARS-CoV-2 and other respiratory viruses. Small 16: e2002169, 2020.

239. Lüthy IA, Ritacco V and Kantor IN: One hundred years after the 'Spanish' flu. Medicina (B Aires) 78: 113-118, 2018 (In Spanish).

(i) This work is licensed under a Creative Commons EY NC ND Attribution-NonCommercial-NoDerivatives 4.0 International (CC BY-NC-ND 4.0) License. 